\title{
Techno-economic analysis of solar stills using integrated fuzzy analytical hierarchy process
} and data envelopment analysis

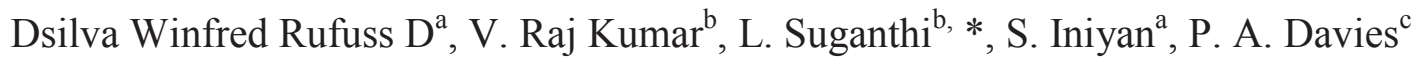

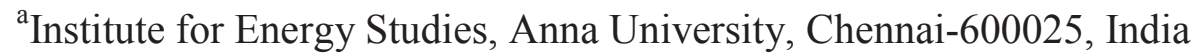 \\ ${ }^{b}$ Department of Management Studies, College of Engineering Guindy, Anna University, \\ Chennai-600025, India
}

${ }^{\mathrm{c}}$ Sustainable Environment Research Group, School of Engineering and Applied Science, Aston University, Birmingham, B4 7ET, UK

*Corresponding author: suganthi_au@yahoo.com

\begin{abstract}
Desalination using solar stills is an ancient economic method for water desalination. Over the years, research and development in the area of solar still has resulted in increased distillate yield by means of integration of PCM (phase change material), photo-voltaic thermal (PVT), etc with the still. Nano-PCM is an upcoming technology which modifies the thermal performance of PCM. The aim of this research is to analyze the efficiency of 20 solar stills including nano-PCM based solar stills considering various input and output criteria using integrated fuzzy analytical hierarchy process (AHP) and data envelopment analysis (DEA). The efficiency derived here is relative with regard to the parameters and stills considered in this study. The result infers that, even though the productivity of stepped solar still with sun tracking system was high, but when techno-economic aspects were considered it is not among the top solar stills. The analysis indicated pyramid type solar still, single slope solar still with PVT, solar still with NPCM (paraffin + copper oxide), solar still with NPCM (paraffin + titanium dioxide) and solar still with PCM (paraffin) occupies the top five positions with relative efficiency of 100, 100, 88.47, 88.46 and $76.93 \%$ respectively.
\end{abstract}

\section{Keywords}

Solar stills; Fuzzy AHP DEA; Relative efficiency; MCDM

\section{Introduction}

Solar desalination is a type of desalination process in which evaporation and condensation processes are driven by solar energy. Among the various types of solar desalination processes, solar stills are significant because of their low environmental impact, technical simplicity, low capital and maintenance cost (Dsilva Winfred Rufuss et al., 2016). Solar still can be used in extremely adverse environments, where there is no source of power for running the otherwise efficient desalination process (Dsilva Winfred Rufuss et al., 2016). Various researchers have modified the conventional solar still to improve its productivity. However this led to an increase in capital and maintenance cost. Studies carried out by earlier researchers (El-Bialy et al., 2016; Kabeel et al., 2010) determined the various costs of solar stills. However, there is no study found in the literature review so far which presents an optimized multi-criteria decision model (MCDM) that considers various criteria such as cost, employee's skill, productivity and technical 
features of solar stills. These aspects need to be considered to ascertain the importance of each criteria for the selection of an ideal solar still that can be taken up for commercialization. This paper focuses on the MCDM approach to analyze the relative efficiency of solar stills based on various input and output criteria using an integrated fuzzy AHP model.

There are various criteria / parameters influencing a solar still such as atmospheric condition, design and economics. Atmospheric condition includes weather, ambient temperature, location, and latitude / longitude degrees. The design aspect includes area, glass cover inclination, brine depth, solar intensity, productivity, salt concentration and insulators. Economic aspects include present capital cost, annual maintenance/ operational cost, annual salvage value and cost of distilled water per litre. Hence selection of a solar still for commercialization needs to be done by considering such parameters as mentioned above. In this paper, fuzzy analytical hierarchy process (AHP) and data envelopment analysis (DEA) techniques are used to optimize some of the above mentioned parameters to arrive at an efficiency for each still relative to the parameters considered. Generally, technical (thermodynamic) efficiency will be used in the comparison of solar stills which considers only the technical aspects. In this study in addition to technical aspects other parameters are considered and the efficiency is obtained relative to the parameters and the stills considered. Technical efficiency is an absolute efficiency that can be compared across various stills while relative efficiency is constrained within the parameters used and the stills used in the study.

Many researchers have used fuzzy AHP techniques in desalination systems like multi-stage desalination (MSD), reverse osmosis (RO), multi-stage flash desalination (MSF), vapor compression (VC) and multi-effect distillation (MED). Fuzzy logic was used in controlling the upper saline water temperature of MSD plants. The research also focused on controlling various parameters for implementing MSD plants in the selected location (Ismail, 1998). Various operational constraints was adopted for implementing a RO desalination plant using fuzzy logic. The proposed methodology resulted in profit for the plant by increasing the availability and decreasing the manpower requirement for RO implementation (Zilouchian and Jafar, 2001). Fuzzy logic was adopted for analyzing MSF and RO systems using various control parameters like brine salinity, pre-heating (Gambier and Badreddin, 2003). Water potential was assessed for irrigation and human consumption using fuzzy logic. It was found that the water used for irrigation is more important than for human consumption (Tsakiris et al., 2009). Major factors which affect the daily productivity of solar still was analyzed using fuzzy logic (Mamlook and Badran, 2007). The same authors (Mamlook and Al-Rawajfeh, 2008) extended the research by using fuzzy logic to analyze which of those factors affect the productivity of MED. The various factors considered in their research included top saline water temperature, $\mathrm{pH}$, temperature and salinity of the sea water. The AHP was used to determine the most suitable desalination process considering seven factors. The desalination processes considered in the research include MSD, MSF, RO and VC. The factors considered were water quality, recovery ratio, consumption of energy, efficiency of instruments and total cost (Hajeeh and Al-Othman, 2005). Various water conservation policies in Kuwait was analyzed using fuzzy AHP. Reusing treated brine water, promoting water conservation were some of their recommendations (Hajeeh, 2010). It is found from the literature that researchers have used fuzzy (Gambier and Badreddin, 2003; Ismail, 1998; Mamlook and Al-Rawajfeh, 2008; Mamlook and Badran, 2007; Tsakiris et al., 2009; Zilouchian 
and Jafar, 2001), AHP (Hajeeh and Al-Othman, 2005), fuzzy AHP (Hajeeh, 2010) in desalination systems.

Integrated fuzzy AHP DEA approach can be used in energy related areas like solar photovoltaic, solar thermal, wind, desalination, power stations, materials and metallurgical applications to determine the weights of influencing parameters and to find the relative efficiency among a set of energy systems. Some researchers used fuzzy for finding the efficiency frontier in petrochemical industries (Taylan et al., 2016), generation sector (Mojallizadeh and Badamchizadeh, 2017; Tanha Aminloei and Ghaderi, 2010; Yu and Dexter, 2010). AHP was used for categorizing frontier energy industries in manufacturing sector (Jovanović et al., 2015) and integrated fuzzy AHP DEA approach has been used (Criswell and Thompson, 1996; Lee et al., 2013, 2011) for finding the relative efficiency of energy technology and hydrogen energy technologies.

Fuzzy logic helps in arriving at concrete estimates despite the vagueness of human thought. AHP helps in obtaining the relative weights for a set of critical attributes. The benefits of integrating fuzzy logic and AHP is to achieve precision in determining the relative importance of criteria and to develop a hierarchal structure for the multi-criteria decision making purpose. It can handle both linguistic assignment and numerical values. The benefits of applying an integrated fuzzy AHP approach to solar still is to determine the relative importance/weights of criteria that affects the performance and efficiency of solar still. DEA is a benchmarking technique employed to know the frontier in the selected area by estimating the relative efficiency of various decision making units (DMU). The benefits of integrating fuzzy AHP and DEA are to find the relative efficiency of DMU considering the weights of criteria obtained from fuzzy AHP. The advantage of implementing such an approach in solar still is to rank and prioritize the important criteria which is involved in the performance, efficiency and productivity of a solar still. Also, the relative efficiency of various solar stills by considering both technical and economic factors can be determined by giving due importance to the influencing criteria. The main objective of other techno-economic analysis (TEA) such as top-down or bottom-up cost approach is to determine the cost and technical feasibility of a particular system (here solar still) and compare the results. In this paper, the integrated approach (fuzzy AHP DEA) is a step ahead i.e., it helps to evaluate the relative efficiency of various solar stills considering several criteria simultaneously to arrive at an optimal decision. The pros of the integrated fuzzy AHP DEA are: comparative analysis of different variant of targets (here solar stills), any measurable criteria for all variant of solar still can be used in DEA, reverse coding of input and output criteria is possible, improvement criteria for the selected parameters can be identified and implemented, human preference can also be incorporated in DEA and fuzzy AHP DEA can be incorporated as a complement to other techniques. As every approaches have some cons associated with them, similarly this integrated fuzzy AHP DEA also has some cons such as: difficulty arises if there is a missing value in the dataset and weak assumption in DEA may lead to underestimation of the relative efficiency of decision making units.

Further, this integrated fuzzy AHP DEA approach can also be used in other energy-related areas including solar photovoltaic, solar thermal, wind, desalination, power stations, materials and metallurgical applications to determine the weights of influencing parameters and to find the relative efficiency among a set of energy systems. It is concluded that, even though various 
researchers used fuzzy and AHP techniques in desalination systems, no one has used an integrated fuzzy-AHP-DEA analysis for analysing the different solar stills. Hence this research gap is addressed in this paper in addition to analyzing the innovative nano-PCM based solar stills from a techno-economic viewpoint. Nanoparticles were incorporated with PCM to modify its thermal properties like thermal conductivity, latent heat of vaporization and decreasing its charging and discharging rate (Dsilva Winfred Rufuss et al., 2017; Kamaraj et al., 2016). Even though nanoparticles improve the thermal properties of PCM in solar still, economic feasibility of the solar still with nano-PCM is one of the essential parameter that needs to be analyzed. Three input criteria namely fabrication/installation cost, skilled labour requirement and land area requirement are considered along with four output criteria namely annual cost, commercial potential, annual productivity and technical complexity. An integrated fuzzy-AHP-DEA analysis is carried out to determine the relative efficiencies of 20 solar stills (for which the data is available for the parameters considered). Also, the relative weights of each criteria and their importance with reference to a particular still are determined.

\section{Solar stills}

Desalination is an essential response to the growing water scarcity problem. It has been reported in our previous paper (Dsilva Winfred Rufuss et al., 2016) that, by the year 2030 half of the world population will experience severe water crisis. There are various desalination process available to desalinate the saline water, of which solar still holds its significance owing to its enviro-economic friendly nature (Kaushal and Varun, 2010; Sathyamurthy et al., 2017; Velmurugan and Srithar, 2011). Solar stills work by the evaporation and condensation processes similar to natural rain. A detailed classification of the desalination process and solar stills are represented graphically in Fig. 1 and Fig. 2 respectively. Low productivity is a major drawback in solar stills, and hence extensive research work has been carried to improve the productivity by modifying the design and operational parameters (Ahsan et al., 2012; Arunkumar et al., 2013, 2012; Gaur and Tiwari, 2010; Murugavel et al., 2010; Rahbar et al., 2016; Sakthivel et al., 2010; Sharshir et al., 2016). The various design and operational parameters are comprehensively listed in Fig. 3.

The basic model of solar still is called a simple single slope solar still. This does not have any enhancements present for augmenting the productivity. The setup of simple single slope solar still is depicted in Fig. 4.

Insert Fig. 1. Detailed tabulation showing classification of desalination processes (Nayi and Modi, 2018)

Insert Fig. 2. Various types of solar stills (Tiwari and Sahota, 2017)

Insert Fig. 3. Various climate, design and operational parameters influencing the productivity of solar still (Muftah et al., 2014)

Insert Fig. 4. Setup of simple single slope solar still (Ali Samee et al., 2007)

Researchers tried to add various components like sun tracker (Abdallah et al., 2008), photovoltaic-thermal (PVT) (Kumar and Tiwari, 2009), collector (Badran and Al-Tahaineh, 2005), 
concentrator (Abdel-Rehim and Lasheen, 2007) and fin (Velmurugan et al., 2008a) to improve the productivity. This resulted in changes in other parameters also namely fabrication cost, skill level of labourers required to construct the solar still, complexity, land area requirement. The pictorial representations of solar stills with sun tracker, PVT, collector, concentrator and fin are depicted in Fig. 5, Fig. 6, Fig. 7, Fig. 8 and Fig. 9 respectively.

Insert Fig. 5. Schematic of solar still with sun tracking system (Abdallah et al., 2008)

Insert Fig. 6. Solar still integrated with photo-voltaic thermal (PVT) system (Kumar and Tiwari, 2009)

Insert Fig. 7. Solar still integrated with flat-plate collector (Badran and Al-Tahaineh, 2005)

Insert Fig. 8. Schematic of solar still integrated with concentrators (Abdel-Rehim and Lasheen, 2007)

Insert Fig. 9. Schematic setup of solar still integrated with fin (Velmurugan et al., 2008a)

Some researchers tried to modify the whole design of the solar still with unconventional shapes i.e, hemispherical (Ismail, 2009) and pyramid shapes (Fath et al., 2003). The design setup of hemispherical and pyramid solar still is depicted in Fig. 10 and Fig. 11 respectively. These modifications resulted in increasing the technical complexity and skilled labour required for fabrication, erection and maintenance and decreased the land area requirement as compared to conventional solar stills.

Insert Fig. 10. Pictorial representation of hemispherical solar still (Ismail, 2009)

Insert Fig. 11. Schematic configuration of pyramid type solar still (Fath et al., 2003)

The energy storage experts tried to integrate energy storage in solar still applications using wick, sponge (Velmurugan et al., 2008b), phase change materials (Shalaby et al., 2016) was integrated to solar stills to enhance the productivity. The solar still with wick, sponge and phase change materials are depicted in Fig. 12 and Fig. 13 respectively. This type of integration has no change on the land area requirement and has a slight increase on other factors like technical complexity, fabrication cost. In recent years, researchers have tried using nanoparticle impregnation in PCM for solar still applications. It was inferred from the literature that the impregnation of nanoparticles in PCM may either improve or impair the thermal properties of the base material (Dsilva Winfred Rufuss et al., 2017; Rao Nulakani et al., 2015).

As stated earlier these kinds of modifications end up with an increase in fabrication cost, technical complexity and skilled labour. Hence there is a need to identify a still with optimum factors. The criteria measured before the fabrication of solar stills are considered as input criteria and the criteria involved in the commercialization are considered as output criteria. In this research skilled labour requirement (SL), fabrication and installation cost (FC) and land area requirement (LA) are considered as the input criteria while economic impact (EI), commercial potential (CP), productivity (P) and technical complexity (TC) are considered as the output 
criteria for the integrated fuzzy analytical hierarchy process. The analysis will help us to determine the unique contribution with respect to a certain criteria as well as its relative importance vis-à-vis other criteria. The traditional top down or bottom up approaches for technoeconomic analysis will only present the overall cost comparison among the solar stills while the present analysis will clearly highlight how concentration on a specific input criteria will improve the overall efficiency of a solar still as well as the efficiency for each of the output criteria.

Insert Fig. 12. Schematic of solar still with sponge (Velmurugan et al., 2008b)

Insert Fig. 13. Solar still with phase change material (PCM) (Shalaby et al., 2016)

\section{Methodology}

The empirical analysis is carried out by collecting various quantitative data on the input/output criteria of the solar still. In this research, fabrication costs (FC) for the 16 solar stills are taken from the literature (Abdallah et al., 2008; Abdallah and Badran, 2008; Abdel-Rehim and Lasheen, 2007; Ali Samee et al., 2007; Badran et al., 2005; Badran and Al-Tahaineh, 2005; ElBahi and Inan, 1999; El-Bialy et al., 2016; El-Sebaii et al., 2008; Fath et al., 2003; Ismail, 2009; Kabeel et al., 2010; Kumar and Tiwari, 2009; Velmurugan et al., 2009, 2008a, 2008b; Velmurugan and Srithar, 2007; Voropoulos et al., 2001) while for the remaining four stills Solar stills with PCM, Nano PCM namely titanium dioxide, copper oxide, graphene oxide, data is obtained from the investigation carried out using the experimental setup in the Institute for Energy Studies, Anna University Chennai, India (Dsilva Winfred Rufuss et al., 2017; Rufuss et al., 2015). The various scales for the input/output criteria such as SL, LA, EI, CP, P and TC are tabulated in Table.1. The overall methodology adopted in the study using this integrated approach is clearly depicted in Fig. 14.

Insert Table 1 Five point scale for various input and output criteria

Insert Fig. 14. Overall methodology of integrated fuzzy AHP DEA

\subsection{Applying the Fuzzy AHP method}

AHP helps in finding the importance of criteria as a hierarchical structure. Experts were identified based on their domain knowledge in the field of renewable energy with special reference to solar energy and solar stills. They were asked to give the relative ratings for pairwise comparisons of the criteria. The consistency of each expert is determined as follows (Lee et al., 2013, 2011; Tanha Aminloei and Ghaderi, 2010; Taylan et al., 2016):

$$
\mathrm{CI}=\frac{\lambda_{\max }-\mathrm{n}}{\mathrm{n}-1}
$$

where $\lambda_{\max }$ and $\mathrm{n}$ are the principal eigenvalue and dimension of the matrix. The pairwise comparison is accepted only if the $\mathrm{CR} \leq 0.10$. Consistency ratio (CR) is the ratio of consistency index $(\mathrm{CI})$ to random index $(\mathrm{RI})[14,15]$. 


$$
\mathrm{CR}=\frac{\mathrm{CI}}{\mathrm{RI}}
$$

The analysis is repeated for each expert for the input and output criteria. Though AHP captures the preference of expert, fuzzy AHP is used to determine the priority weights of the input and output criteria using hierarchical fuzzy decision making process.

The triangular fuzzy scale (TFN) and the inverse scale are given in Table 2.

Insert Table 2 Triangular fuzzy (TFN) scale and its inverse TFN scale

Let $\quad M_{i j}=\left(l_{i j}, m_{i j}, u_{i j}\right)$

$\mathrm{M}_{\mathrm{ij}}$ be the TFN for a fuzzy pair wise comparison judgment, where $1, \mathrm{~m}$ and $\mathrm{u}$ are lower, mid and upper limit respectively.

The synthetic extent value with respect to $i^{\text {th }}$ object is calculated using the following formulas $[14,15]$

$$
\begin{gathered}
S_{i}=\sum_{j=1}^{m} M_{i j}\left[\sum_{i=1}^{n} \sum_{j=1}^{m} M_{i j}\right]^{-1} \\
\sum_{j=1}^{m} M_{i j}=\left(\sum_{j=1}^{m} l_{i j}, \sum_{j=1}^{m} m_{i j}, \sum_{j=1}^{m} u_{i j}\right), i=1,2,3,4, \ldots, n \\
\sum_{i=1}^{n} \sum_{j=1}^{m} M_{i j}=\left(\sum_{i=1}^{n} \sum_{j=1}^{m} l_{i j}, \sum_{i=1}^{n} \sum_{j=1}^{m} m_{i j}, \sum_{i=1}^{n} \sum_{j=1}^{m} u_{i j}\right) \\
{\left[\sum_{i=1}^{n} \sum_{j=1}^{m} M_{i j}\right]^{-1}=\left(\frac{1}{\sum_{i=1}^{n} \sum_{j=1}^{m} u_{i j}}, \frac{1}{\sum_{i=1}^{n} \sum_{j=1}^{m} m_{i j}}, \frac{1}{\sum_{i=1}^{n} \sum_{j=1}^{m} l_{i j}}\right)}
\end{gathered}
$$

The value of $S_{i}$ is then determined and the degree of possibility of $S_{j}=\left(l_{j}, m_{j}, u_{j}\right) \geq S_{i}=\left(l_{i}, m_{i}, u_{i}\right)$ is expressed by the following equation $[14,15]$.

$$
V\left(S_{j} \geq S_{i}\right)=\operatorname{height}\left(S_{i} \cap S_{j}\right)=u_{s_{j}}(d)= \begin{cases}1, & \text { if } m_{j} \geq m_{i} \\ 0, & \text { if } l_{i} \geq u_{j} \\ \frac{l_{i}-u_{j}}{\left(m_{j}-u_{j}\right)-\left(m_{i}-l_{i}\right)}, & \text { otherwise }\end{cases}
$$

The minimum degree of possibility $d^{\prime}$ (i) of $V\left(S_{i} \geq S_{j}\right)$ for $i=1,2,3, . ., k$ and $j=1,2,3, . ., k$ is calculated using $[14,15]$

$$
\begin{gathered}
\mathrm{V}\left(\mathrm{S} \geq \mathrm{S}_{1}, \mathrm{~S}_{2}, \ldots, \mathrm{S}_{\mathrm{k}}\right) \text { for } \mathrm{i}=1,2, \ldots, \mathrm{k}=\mathrm{V}\left[\left(\mathrm{S} \geq \mathrm{S}_{1}\right) \operatorname{and}\left(\mathrm{S} \geq \mathrm{S}_{2}\right) \text { and.. }\left(\mathrm{S} \geq \mathrm{S}_{\mathrm{k}}\right)\right] \\
=\min \mathrm{V}\left(\mathrm{S} \geq \mathrm{S}_{\mathrm{i}}\right) \text { for } \mathrm{i}=1,2, \ldots, \mathrm{k}
\end{gathered}
$$




$$
\text { Assume } d^{\prime}\left(A_{i}\right)=\min V\left(S \geq S_{i}\right) \text { for } 1=12, \ldots, k
$$

The weight vector is found using the equation $[14,15]$

$$
W^{\prime}=\left(d^{\prime}\left(A_{1}\right), d^{\prime}\left(A_{2}\right), \ldots, d^{\prime}\left(A_{n}\right)\right)^{T} \text { where } A_{i}(i=1,2,3,4, \ldots, n) \text { are the } n \text { elements }
$$

The weight vectors are then normalized to get the relative weight using the formula $[14,15]$

$$
W=\left(d\left(A_{1}\right), d\left(A_{2}\right), \ldots, d\left(A_{n}\right)\right)^{T}
$$

where $\mathrm{W}$ is a non-fuzzy number indicating the relative weight of the criteria.

\subsection{Measuring the relative efficiency using DEA}

The relative efficiency of various types of solar still is calculated by using DEA approach. Fig. 15 , shows the hierarchy of the DEA process which consist of three input and four output criteria. DEA is an analytical technique used to determine the efficient utilization of resources in a decision making unit (DMU). The model developed by (Charnes et al., 1978) is adopted to find the relative efficiency. The DEA formulation is as follows:

There are $\mathrm{n}$ units with $\mathrm{s}$ outputs denoted by $\mathrm{Y}_{\mathrm{rk}}, \mathrm{r}=1,2, . ., \mathrm{s}$ and $\mathrm{m}$ inputs denoted by $\mathrm{X}_{\mathrm{ik}}$, $\mathrm{i}=1,2, \ldots, \mathrm{m}$, the efficiency score $\left(\mathrm{h}_{\mathrm{k}}\right)$ for the $\mathrm{DMU}_{\mathrm{k}}$

$$
\mathrm{h}_{\mathrm{k}}=\operatorname{Max} \frac{\sum_{\mathrm{r}=1}^{\mathrm{s}} \mathrm{u}_{\mathrm{rk}} \mathrm{Y}_{\mathrm{rk}}}{\sum_{\mathrm{i}=1}^{\mathrm{m}} \mathrm{v}_{\mathrm{ik}} \mathrm{X}_{\mathrm{ik}}}
$$

where $\mathrm{u}_{\mathrm{r}}$ and $\mathrm{v}_{\mathrm{i}}$ are non-negative weights.

In order to obtain the efficiency of DMU in such a manner that they are not greater than 1 , the equations are rewritten as follows:

$$
\begin{gathered}
\text { s.t } \frac{\sum_{\mathrm{r}=1}^{\mathrm{s}} \mathrm{u}_{\mathrm{rk}} \mathrm{Y}_{\mathrm{rk}}}{\sum_{\mathrm{i}=1}^{\mathrm{m}} \mathrm{v}_{\mathrm{ik}} \mathrm{X}_{\mathrm{ik}}} \leq 1, \text { for } \mathrm{j}=1,2,3, \ldots, \mathrm{n} \\
\mathrm{u}_{\mathrm{rk}}>0, \text { for } r=1,2,3, \ldots, s \\
\mathrm{v}_{\mathrm{ik}}>0, \text { for } i=1,2,3, \ldots, m
\end{gathered}
$$

The efficiency ranges between 0 and 1 . The system with maximum efficiency is the system lying in the efficient frontier and is considered to be the best as compared to the other systems. The above equation is transformed to a linear programming problem one for each DMU as follows (Lee et al., 2013, 2011):

$$
\mathrm{h}_{\mathrm{k}}=\max \sum_{\mathrm{r}=1}^{\mathrm{s}} \mathrm{u}_{\mathrm{r}} \mathrm{Y}_{\mathrm{rk}}
$$




$$
\begin{aligned}
& \text { s.t } \sum_{i=1}^{m} v_{i} X_{i j}- \sum_{r=1}^{s} u_{r} Y_{r j} \geq 0 \text { for } j=1,2,3, \ldots, n \\
& \sum_{i=1}^{m} v_{i} X_{i k}=1 \\
& u_{r} \geq 0 \text { for } r=1,2,3, \ldots, s \text { (19) } \\
& v_{i} \geq 0 \text { for } i=1,2,3, \ldots, m
\end{aligned}
$$

Insert Fig. 15. Hierarchical structure of various input and output criteria used in DEA

The model obtained is referred to as the CCR model. This CCR model assumes that the production components are constant return-to-scale. Assurance region (AR) is selected to avoid null outputs in the analysis. In AR-CCR model, a set of new constrains will be included in the above model in such a way that the weights are restricted with a lower and upper bound.

$$
\mathrm{L}_{1,2} \leq \frac{\mathrm{u}_{\mathrm{j} 1}}{\mathrm{u}_{\mathrm{j} 2}} \leq \mathrm{U}_{1,2}
$$

where $\mathrm{L}_{1,2}$ and $\mathrm{U}_{1,2}$ are lower and upper bound. $\mathrm{u}_{\mathrm{j} 1}$ and $\mathrm{u}_{\mathrm{j} 2}$ present the weight achieved by the $\mathrm{DMU}_{\mathrm{j}}$. By adding equation 21 in the CCR model, AR-CCR model is obtained.

\section{Results and discussion}

Researchers have been working in various types of solar still and have identified several technically viable stills. However, for a still to be made commercially viable we need to study the social and economic aspects in addition to technical aspects. Such a study which integrates energy production and energy efficiency parameters across various energy systems from a techno-economic viewpoint needs to be done to obtain a realistic estimate of an energy system. In this study, energy production parameters namely productivity, commercial potential; energy efficiency parameters namely technical complexity; economic parameters namely fabrication and maintenance costs; social parameters namely employee skill level, land area have been considered and studied in the MCDM analysis.

\subsection{Fuzzy AHP DEA approach}

Experts were chosen based on their teaching, research and industrial experience in the domain area namely renewable energy, desalination and solar stills. The choice of the number of experts depend on the availability of the experts and their accessibility. There is no literature available which specifies the number of experts to be chosen for AHP based decision making process (Nixon et al., 2010). The outcome varies as the expert size varies since, greater the number of experts, arriving at a consensus becomes complex due to the uncertainty in the decision making process. The judgement of the experts should have minimum variability with high level of confidence and convergence. In general practice, literatures indicate that smaller expert size kindles effective impact and involvement which lead to the group unanimity (Dey, 2004; Nixon 
et al., 2010). The consistency ratio of the experts was found and the response of 10 experts was then used for further analysis. The demographic details of the experts are given in Table 3.

\section{Insert Table 3 Demographic details of the experts}

The experts were asked to rank the relative importance of the various input and output criteria using AHP relative importance scale. Using the relative importance score given by the experts, the CR for each expert was determined for each of the input/output criteria and the values are tabulated in Table 4. From the Table 4, it is found that the CR value for all the ten experts are less than 0.1. Hence all the experts' opinion are considered valid and used for further analysis. The synthetic weight was then determined for the input and output criteria for each of the expert. The procedure adopted is presented for one expert for the input criteria. This procedure is repeated for all the experts as well as for the output criteria. The pairwise comparison of TFN value of one expert (expert-1) using Table 2 is shown in Table 5.

Insert Table $4 \mathrm{CR}$ value for the input and output criteria

Insert Table 5 Pairwise comparison

Using the equation (4), (5), (6) and (7), the synthetic weights are obtained as follows.

$$
\begin{gathered}
S_{1}(S L)=(3,3.666,4.5) \otimes\left(\frac{1}{12.333}, \frac{1}{10.166}, \frac{1}{8.3}\right) \\
S_{2}(F C)=(1.8,2,2.33) \otimes\left(\frac{1}{12.33}, \frac{1}{10.166}, \frac{1}{8.3}\right) \\
S_{3}(L A)=(3.5,4.5,5.5) \otimes\left(\frac{1}{12.33}, \frac{1}{10.166}, \frac{1}{8.3}\right)
\end{gathered}
$$

The degree of possibility $S_{j}$ (equation 8) is given in Table 6 .

Insert Table 6 Comparing the values of fuzzy synthetic extent

The minimum degree of possibility d' (i) found using equation 9 is as follows:

$\mathrm{d}^{\prime}(1)=\min \mathrm{V}\left(\mathrm{S}_{1} \geq \mathrm{S}_{2}, \mathrm{~S}_{3}\right)=0.7591$

$\mathrm{d}^{\prime}(2)=\min \mathrm{V}\left(\mathrm{S}_{2} \geq \mathrm{S}_{1}, \mathrm{~S}_{3}\right)=0$

$\mathrm{d}^{\prime}(3)=\min \mathrm{V}\left(\mathrm{S}_{3} \geq \mathrm{S}_{1}, \mathrm{~S}_{2}\right)=1$

Using equation 10, the weight vector is determined and their relative weights are shown below

$\mathrm{W}^{\prime}=(0.7591,0,1)^{\mathrm{T}}$

Hence the relative weights are

$\mathrm{W}=(0.43155,0,0.56845)^{\mathrm{T}}$ 
The same procedure is repeated for each of the ten experts and the weights are listed in Table 7. The lower and upper bound is calculated by considering the minimum and maximum values of the weights. These weights are then incorporated in Charnes, Cooper, Rhodes (CCR) model. The upper and lower bounds for the input criteria are tabulated in Table 8. Similarly the weights of ten experts are determined for the output criteria and the values are presented in Table 9. Also, the lower bound and the upper bound values are obtained for the output criteria and the corresponding values are tabulated in Table 10. The quantitative data used in the analysis for the 20 stills is presented in Table 11 and the radar chart depicting their input/output criteria is represented in Fig. 16. From the radar chart, it is clear that certain solar stills (such as still with wick, hemispherical solar still, stepped still, weir type still, still with collector, concentrator and fin), should improve its commercial potential and productivity or reduce their fabrication cost to reach the top position. The data is normalized and used for further analysis. DEA model is run using the add-in package available in Microsoft Excel. The weight distribution of AR-CCR (with weight restriction) for the 20 stills is shown in Table 12.

Insert Table 7 Fuzzy AHP weights for Input criteria

Insert Table 8 Upper and lower bounds of weights input criteria

Insert Table 9 Fuzzy AHP weights for output criteria

Insert Table 10 Upper and lower bounds of weights output criteria

Insert Table 11 Input/output criteria for 20 solar stills

\section{Insert Table 12 Weight distribution of AR-CCR (with weight restriction)}

Insert Fig. 16. Input/output criteria for the twenty solar stills

Here the various stills are considered as decision making units. The productive efficiency decomposition of the various DMU's (in this case, various solar stills) is obtained from the ARCCR model and given in Table 13. The efficiency decomposition of twenty solar stills is depicted in Fig. 17. For the solar still with wick and fin to be on the frontier, it is necessary to reduce the skilled labour requirement or increase its economic impact. For a transportable hemispherical solar still to reach the efficiency frontier, we should reduce its fabrication cost and land area requirement. In the case of solar still with wick and sponge, we should improve its commercial potential and technical complexity. In the case of the stepped solar still with sun tracking system, we should reduce its fabrication cost, skilled labour requirement and improve its economic impact. For a weir type solar still, we should focus on improving its economic impact and productivity. The solar still with sponge \& pond, shallow pond and condenser require improvements in their economic impact and productivity or reduce their fabrication cost and land area requirement. For the solar still with collector and concentrator, we should either reduce its technical complexity and skilled labour requirement or improve its economic impact and commercial potential. Pyramid type solar stills should improve its commercial potential, economic impact and productivity. In the case of solar still with PCM and nano-PCM's, it is important to reduce fabrication cost and skilled labour requirement or improve its economic impact and commercial potential to reach the efficiency frontier. 


\section{Insert Fig. 17. Efficiency decomposition of twenty solar stills}

When the efficiency of a solar still is $1.00(100 \%)$, then that particular solar still is in the efficiency frontier and is considered to be the most efficient solar still considering all the input and output criteria. From the DEA results, a pyramid type solar still and single slope solar still with PVT lies in the efficiency frontier and are the most efficient solar stills. Solar still with Nano PCM (Copper oxide) and solar still with Nano PCM (Titanium dioxide) come next with the efficiency of 0.8847 and 0.8846 respectively. Solar still with graphene oxide, though technically the best solar still (Dsilva Winfred Rufuss et al., 2016; Rufuss et al., 2015), is completely ruled out since its efficiency is only 0.487 . In the case of NPCM based solar still (solar still with copper oxide and titanium dioxide) [ranked no.3 and 4] to reach the efficiency frontier there is $12 \%$ lag. Solar still with copper oxide needs to either decrease its skilled labour requirement or increase its economic impact / commercial potential to become the most efficient solar still. Similarly for solar still with titanium dioxide to improve its efficiency position, research has to be done to improve its economic impact and commercial potential.

To summarize, among the various types of solar still technologies, the top five stills which are both technically and economically efficient are pyramid type solar still, single slope solar still with PVT, solar still with NPCM (copper oxide), solar still with NPCM (titanium dioxide) and solar still with PCM. The remaining stills are either technically strong or economically strong. For example, transportable hemispherical solar still and stepped solar still with sun tracking system are technically strong, but when we consider both technical and economic aspects, it is not found among the best solar still technologies. In general, it is recommended that the relative efficiency of solar stills can be enhanced either by decreasing the cost of skilled labour (SL), fabrication (FC), and land area requirement (LA) or by increasing its economic impact (EI), commercial potential (CP), productivity $(\mathrm{P})$ and technical complexity (TC). Hence future research and development in solar stills must be carried out by considering both technical and economic aspects for effective commercialization of solar still technology.

\subsection{Applications and recommendation for future works}

This techno-economic approach to solar stills will be useful for industrialist to identify the pros and cons of various solar stills. It will help them to select a solar still based on their indigenous resource availability and their strengths. For example, if there is a policy initiative to give a $50 \%$ subsidy towards fabrication, then the ranking of stills will undergo a change i.e., pyramid type solar still will take a lead role followed by solar still with NPCM, solar still with pond, and then solar still with PCM. Thus either by increasing the level of the output criteria like productivity, economic impact or decreasing the level of input criteria such as capital cost, labour, efficiency of the energy system can be improved. The values of each parameter in the decomposition table indicates areas where a certain stills can be improved to make it competitive and to reach the efficiency frontier. This integrated fuzzy AHP DEA approach can be used in other desalination system to find the relative efficiency of desalination processes like multi-effect flash distillation (Baig et al., 2011; Choi, 2016; Elzahaby et al., 2016), membrane distillation (Nakoa et al., 2015; Orfi et al., 2016; Wang, 2011; Zhang et al., 2015), FO \& RO(forward and reverse osmosis) 
(Altaee and Hilal, 2015; Delgado-Torres and García-Rodríguez, 2010; Khanzada et al., 2017; Mokheimer et al., 2013; Mudgal and Davies, 2016; Qasim et al., 2015), ion exchange (AlMarzooqi et al., 2014; Hilal et al., 2015a, 2015b), seawater greenhouse techniques (Davies et al., 2004, 2006; Davies and Knowles, 2006; Davies and Paton, 2005; Yetilmezsoy and AbdulWahab, 2014), etc. by selecting the techno-economic input/output parameters.

This integrated approach can also be employed in other applications like renewable energy sectors (solar, wind, tidal, biomass, etc.) and power generation sectors (conventional and nonconventional power plants). In the renewable energy sector, this approach can be used to determine the energy production efficiency in solar and wind. In solar, the relative efficiency of energy production can be investigated by considering various input/output parameters like capacity, location, demand, complexity, land area requirement, etc. for various solar cells such as crystalline silicon solar cell, hybrid solar cell, gallium arsenide solar cell, polymer solar cell, and solid-state solar cell. The energy production and energy efficiency in the wind energy sector can be analyzed using this integrated fuzzy AHP DEA approach by considering input/output parameters like turbine capacity, tower height, power production, land and location, number of blades for various types of wind turbine like vertical axis wind turbine, horizontal axis wind turbine, multi-axis wind turbine, etc. A system which lies on the efficiency frontier can be used as a benchmark for other resource/system to emulate by strengthening of their respective criteria.

\section{Conclusions}

An integrated fuzzy analytical hierarchy process and data envelopment approach is used to analyze the relative efficiency of various solar stills based on various input and output criteria. Relative weights of criteria are found using fuzzy AHP approach and the overall efficiency score for the 20 solar stills is determined using the data envelopment analysis. Though many solar stills are technically strong (high productivity) yet they are not economically strong (high fabrication, operation and maintenance cost) and hence do not find a place among the top solar stills. When the productivity is considered as the only criteria, then hybrid solar still, solar still sun tracking and solar still with solar pond is found to be at the top (Dsilva Winfred Rufuss et al., 2016; Kabeel and El-Agouz, 2011; Yadav and Sudhakar, 2015), but when the other parameters such as fabrication cost, economic impact, etc are considered then pyramid type solar still, still with PVT, still with NPCM $\left(\mathrm{CuO}, \mathrm{TiO}_{2}\right)$ and PCM goes to the top five position with 100, 100, 88, 88 and $77 \%$ relative efficiency respectively. It is inferred that, solar still with copper oxide requires a reduction in the skilled labour requirement or an improvement in its commercial potential and economic impact to reach the top position. Similarly, overall efficiency of other solar stills can be increased by concentrating on the pinpointed areas.

\section{Acknowledgements}

The authors gratefully acknowledge DST and British Council for providing financial support under UKIERI project funding scheme (DST/INT/UK/P-86/2014, UKIERI-DST-2014-15-03). Also, one of the authors Mr. Dsilva Winfred Rufuss gratefully acknowledge the award of Senior Research Fellow (SRF) under the Maulana Azad National Fellowship (MANF) program by the Ministry of Minority Affairs, University Grants Commission (UGC) New Delhi, Proceeding No. MANF-2015-17-TAM-48968. 


\section{References}

Abdallah, S., Badran, O., Abu-Khader, M.M., 2008. Performance evaluation of a modified design of a single slope solar still. Desalination 219, 222-230. doi:10.1016/j.desal.2007.05.015

Abdallah, S., Badran, O.O., 2008. Sun tracking system for productivity enhancement of solar still. Desalination 220, 669-676. doi:10.1016/j.desal.2007.02.047

Abdel-Rehim, Z.S., Lasheen, A., 2007. Experimental and theoretical study of a solar desalination system located in Cairo, Egypt. Desalination 217, 52-64. doi:10.1016/j.desal.2007.01.012

Ahsan, A., Imteaz, M., Rahman, A., Yusuf, B., Fukuhara, T., 2012. Design, fabrication and performance analysis of an improved solar still. Desalination 292, 105-112. doi:10.1016/j.desal.2012.02.013

Ali Samee, M., Mirza, U.K., Majeed, T., Ahmad, N., 2007. Design and performance of a simple single basin solar still. Renew. Sustain. Energy Rev. doi:10.1016/j.rser.2005.03.003

AlMarzooqi, F.A., Al Ghaferi, A.A., Saadat, I., Hilal, N., 2014. Application of Capacitive Deionisation in water desalination: A review. Desalination. doi:10.1016/j.desal.2014.02.031

Altaee, A., Hilal, N., 2015. High recovery rate NF-FO-RO hybrid system for inland brackish water treatment. Desalination 363, 19-25. doi:10.1016/j.desal.2014.12.017

Arunkumar, T., Jayaprakash, R., Ahsan, A., Denkenberger, D., Okundamiya, M.S., 2013. Effect of water and air flow on concentric tubular solar water desalting system. Appl. Energy 103, 109-115. doi:10.1016/j.apenergy.2012.09.014

Arunkumar, T., Jayaprakash, R., Denkenberger, D., Ahsan, A., Okundamiya, M.S., kumar, S., Tanaka, H., Aybar, H.Ş., 2012. An experimental study on a hemispherical solar still. Desalination 286, 342-348. doi:10.1016/j.desal.2011.11.047

Badran, A.A., Al-Hallaq, A.A., Eyal Salman, I.A., Odat, M.Z., 2005. A solar still augmented with a flat-plate collector. Desalination 172, 227-234. doi:10.1016/j.desal.2004.06.203

Badran, O.O., Al-Tahaineh, H.A., 2005. The effect of coupling a flat-plate collector on the solar still productivity. Desalination 183, 137-142. doi:10.1016/j.desal.2005.02.046

Baig, H., Antar, M.A., Zubair, S.M., 2011. Performance evaluation of a once-through multi-stage flash distillation system: Impact of brine heater fouling. Energy Convers. Manag. 52, 14141425. doi:10.1016/j.enconman.2010.10.004

Charnes, A., Cooper, W.W., Rhodes, E., 1978. Measuring the efficiency of decision making units. Eur. J. Oper. Res. 2, 429-444. doi:10.1016/0377-2217(78)90138-8

Choi, S.H., 2016. On the brine re-utilization of a multi-stage flashing (MSF) desalination plant. Desalination 398, 64-76. doi:10.1016/j.desal.2016.07.020

Criswell, D.R., Thompson, R.G., 1996. Data envelopment analysis of space and terrestriallybased large scale commercial power systems for earth: A prototype analysis of their relative economic advantages. Sol. Energy. doi:10.1016/0038-092X(95)00113-6

Davies, P.A., Harris, I., Knowles, P.R., 2006. Cooling of greenhouses using seawater: A solar driven liquid-desiccant cycle for greenhouse cooling in hot climates, in: Acta Horticulturae. pp. 139-146. 
Davies, P.A., Knowles, P.R., 2006. Seawater bitterns as a source of liquid desiccant for use in solar-cooled greenhouses. Desalination 196, 266-279. doi:10.1016/j.desal.2006.03.010

Davies, P.A., Paton, C., 2005. The Seawater Greenhouse in the United Arab Emirates: thermal modelling and evaluation of design options. Desalination 173, 103-111. doi:10.1016/j.desa1.2004.06.211

Davies, P., Turner, K., Paton, C., 2004. Potential of the Seawater Greenhouse in Middle Eastern Climates. Eng. Conf. 523-540.

Delgado-Torres, A.M., García-Rodríguez, L., 2010. Preliminary design of seawater and brackish water reverse osmosis desalination systems driven by low-temperature solar organic Rankine cycles (ORC). Energy Convers. Manag. 51, 2913-2920. doi:10.1016/j.enconman.2010.06.032

Dey, P.K., 2004. Analytic hierarchy process helps evaluate project in Indian oil pipelines industry. Int. J. Oper. Prod. Manag. 24, 588-604. doi:10.1108/01443570410538122

Dsilva Winfred Rufuss, D., Iniyan, S., Suganthi, L., Davies, P.A., 2017. Low mass fraction impregnation with graphene oxide (GO) enhances thermo-physical properties of paraffin for heat storage applications. Thermochim. Acta 655, 226-233. doi:10.1016/j.tca.2017.07.005

Dsilva Winfred Rufuss, D., Iniyan, S., Suganthi, L., Davies, P.A., 2016. Solar stills: A comprehensive review of designs, performance and material advances. Renew. Sustain. Energy Rev. 63, 464-496. doi:10.1016/j.rser.2016.05.068

El-Bahi, A., Inan, D., 1999. Analysis of a parallel double glass solar still with separate condenser. Renew. Energy 17, 509-521. doi:10.1016/S0960-1481(98)00768-X

El-Bialy, E., Shalaby, S.M., Kabeel, A.E., Fathy, A.M., 2016. Cost analysis for several solar desalination systems. Desalination 384, 12-30. doi:10.1016/j.desal.2016.01.028

El-Sebaii, A.A., Ramadan, M.R.I., Aboul-Enein, S., Salem, N., 2008. Thermal performance of a single-basin solar still integrated with a shallow solar pond. Energy Convers. Manag. 49, 2839-2848. doi:10.1016/j.enconman.2008.03.002

Elzahaby, A.M., Kabeel, A.E., Bassuoni, M.M., Elbar, A.R.A., 2016. Direct contact membrane water distillation assisted with solar energy. Energy Convers. Manag. 110, 397-406. doi:10.1016/j.enconman.2015.12.046

Fath, H.E.S., El-Samanoudy, M., Fahmy, K., Hassabou, A., 2003. Thermal-economic analysis and comparison between pyramid-shaped and single-slope solar still configurations. Desalination 159, 69-79. doi:10.1016/S0011-9164(03)90046-4

Gambier, A., Badreddin, E., 2003. Application of hybrid modeling and control techniques to desalination plants. Desalination 152, 175-184. doi:10.1016/S0011-9164(02)01060-3

Gaur, M.K., Tiwari, G.N., 2010. Optimization of number of collectors for integrated PV/T hybrid active solar still. Appl. Energy 87, 1763-1772. doi:10.1016/j.apenergy.2009.10.019

Hajeeh, M., 2010. Journal of industrial engineering international., Journal of Industrial Engineering, International. Islamic Azad University.

Hajeeh, M., Al-Othman, A., 2005. Application of the analytical hierarchy process in the selection of desalination plants. Desalination 174, 97-108. doi:10.1016/j.desal.2004.09.005 
Hilal, N., Kochkodan, V., Al Abdulgader, H., Johnson, D., 2015a. A combined ion exchangenanofiltration process for water desalination: II. Membrane selection. Desalination 363, 5157. doi:10.1016/j.desal.2014.11.017

Hilal, N., Kochkodan, V., Al Abdulgader, H., Mandale, S., Al-Jlil, S.A., 2015b. A combined ion exchange-nanofiltration process for water desalination: I. sulphate-chloride ion-exchange in saline solutions. Desalination 363, 44-50. doi:10.1016/j.desal.2014.11.016

Ismail, A., 1998. Fuzzy model reference learning control of multi-stage flash desalination plants. Desalination 116, 157-164. doi:10.1016/S0011-9164(98)00192-1

Ismail, B.I., 2009. Design and performance of a transportable hemispherical solar still. Renew. Energy 34, 145-150. doi:10.1016/j.renene.2008.03.013

Jovanović, B., Filipović, J., Bakić, V., 2015. Prioritization of manufacturing sectors in Serbia for energy management improvement - AHP method. Energy Convers. Manag. 98, 225-235. doi:10.1016/j.enconman.2015.03.107

Kabeel, A.E., El-Agouz, S.A., 2011. Review of researches and developments on solar stills. Desalination. doi:10.1016/j.desal.2011.03.042

Kabeel, A.E., Hamed, A.M., El-Agouz, S.A., 2010. Cost analysis of different solar still configurations. Energy 35, 2901-2908. doi:10.1016/j.energy.2010.03.021

Kamaraj, M., Sundar, J.V., Subramanian, V., 2016. Dioxin sensing properties of graphene and hexagonal boron nitride based van der Waals solids: a first-principles study. RSC Adv. 6. doi:10.1039/c6ra18976h

Kaushal, A., Varun, 2010. Solar stills: A review. Renew. Sustain. Energy Rev. doi:10.1016/j.rser.2009.05.011

Khanzada, N.K., Khan, S.J., Davies, P.A., 2017. Performance evaluation of reverse osmosis (RO) pre-treatment technologies for in-land brackish water treatment. Desalination 406, 44 50. doi:10.1016/j.desal.2016.06.030

Kumar, S., Tiwari, G.N., 2009. Life cycle cost analysis of single slope hybrid (PV/T) active solar still. Appl. Energy 86, 1995-2004. doi:10.1016/j.apenergy.2009.03.005

Lee, S.K., Mogi, G., Hui, K.S., 2013. A fuzzy analytic hierarchy process (AHP)/data envelopment analysis (DEA) hybrid model for efficiently allocating energy R\&D resources: In the case of energy technologies against high oil prices. Renew. Sustain. Energy Rev. 21, 347-355. doi:10.1016/j.rser.2012.12.067

Lee, S.K., Mogi, G., Li, Z., Hui, K.S., Lee, S.K., Hui, K.N., Park, S.Y., Ha, Y.J., Kim, J.W., 2011. Measuring the relative efficiency of hydrogen energy technologies for implementing the hydrogen economy: An integrated fuzzy AHP/DEA approach. Int. J. Hydrogen Energy 36, 12655-12663. doi:10.1016/j.ijhydene.2011.06.135

Mamlook, R., Al-Rawajfeh, A.E., 2008. Fuzzy set implementation for controlling and evaluation of factors affecting multiple-effect distillers. Desalination 222, 541-547. doi:10.1016/j.desal.2007.01.131

Mamlook, R., Badran, O., 2007. Fuzzy sets implementation for the evaluation of factors affecting solar still production. Desalination 203, 394-402. doi:10.1016/j.desal.2006.02.024

Mojallizadeh, M.R., Badamchizadeh, M.A., 2017. Second-order fuzzy sliding-mode control of 
photovoltaic power generation systems. Sol. Energy 149, 332-340.

doi:10.1016/j.solener.2017.04.014

Mokheimer, E.M.A., Sahin, A.Z., Al-Sharafi, A., Ali, A.I., 2013. Modeling and optimization of hybrid wind-solar-powered reverse osmosis water desalination system in Saudi Arabia. Energy Convers. Manag. 75, 86-97. doi:10.1016/j.enconman.2013.06.002

Mudgal, A., Davies, P.A., 2016. A cost-effective steam-driven RO plant for brackish groundwater. Desalination 385, 167-177. doi:10.1016/j.desal.2016.02.022

Muftah, A.F., Alghoul, M.A., Fudholi, A., Abdul-Majeed, M.M., Sopian, K., 2014. Factors affecting basin type solar still productivity: A detailed review. Renew. Sustain. Energy Rev. doi:10.1016/j.rser.2013.12.052

Murugavel, K.K., Sivakumar, S., Ahamed, J.R., Chockalingam, K.K.S.K., Srithar, K., 2010. Single basin double slope solar still with minimum basin depth and energy storing materials. Appl. Energy 87, 514-523. doi:10.1016/j.apenergy.2009.07.023

Nakoa, K., Rahaoui, K., Date, A., Akbarzadeh, A., 2015. An experimental review on coupling of solar pond with membrane distillation. Sol. Energy 119, 319-331. doi:10.1016/j.solener.2015.06.010

Nayi, K.H., Modi, K. V., 2018. Pyramid solar still: A comprehensive review. Renew. Sustain. Energy Rev. doi:10.1016/j.rser.2017.07.004

Nixon, J.D., Dey, P.K., Davies, P.A., 2010. Which is the best solar thermal collection technology for electricity generation in north-west India? Evaluation of options using the analytical hierarchy process. Energy 35, 5230-5240. doi:10.1016/j.energy.2010.07.042

Orfi, J., Loussif, N., Davies, P.A., 2016. Heat and mass transfer in membrane distillation used for desalination with slip flow. Desalination 381, 135-142. doi:10.1016/j.desal.2015.12.009

Qasim, M., Darwish, N.A., Sarp, S., Hilal, N., 2015. Water desalination by forward (direct) osmosis phenomenon: A comprehensive review. Desalination 374, 47-69. doi:10.1016/j.desal.2015.07.016

Rahbar, N., Esfahani, J.A., Asadi, A., 2016. An experimental investigation on productivity and performance of a new improved design portable asymmetrical solar still utilizing thermoelectric modules. Energy Convers. Manag. 118, 55-62. doi:10.1016/j.enconman.2016.03.052

Rao Nulakani, N.V., Kamaraj, M., Subramanian, V., 2015. Coro-graphene and circumcorographyne: novel two-dimensional materials with exciting electronic properties. RSC Adv. 5, 78910-78916. doi:10.1039/C5RA14477A

Rufuss, D.D.W., Iniyan, S., Suganthi, L., Davies, P.A., Akinaga, T., 2015. Analysis of solar still with nanoparticle incorporated phase change material for solar desalination application 812.

Sakthivel, M., Shanmugasundaram, S., Alwarsamy, T., 2010. An experimental study on a regenerative solar still with energy storage medium - Jute cloth. Desalination 264, 24-31. doi:10.1016/j.desal.2010.06.074

Sathyamurthy, R., El-Agouz, S.A., Nagarajan, P.K., Subramani, J., Arunkumar, T., Mageshbabu, D., Madhu, B., Bharathwaaj, R., Prakash, N., 2017. A Review of integrating solar collectors to solar still. Renew. Sustain. Energy Rev. doi:10.1016/j.rser.2016.11.223 
Shalaby, S.M., El-Bialy, E., El-Sebaii, A.A., 2016. An experimental investigation of a vcorrugated absorber single-basin solar still using PCM. Desalination 398, 247-255. doi:10.1016/j.desal.2016.07.042

Sharshir, S.W., Peng, G., Yang, N., Eltawil, M.A., Ali, M.K.A., Kabeel, A.E., 2016. A hybrid desalination system using humidification-dehumidification and solar stills integrated with evacuated solar water heater. Energy Convers. Manag. 124, 287-296. doi:10.1016/j.enconman.2016.07.028

Tanha Aminloei, R., Ghaderi, S.F., 2010. Generation planning in Iranian power plants with fuzzy hierarchical production planning. Energy Convers. Manag. 51, 1230-1241. doi:10.1016/j.enconman.2009.12.034

Taylan, O., Kaya, D., Demirbas, A., 2016. An integrated multi attribute decision model for energy efficiency processes in petrochemical industry applying fuzzy set theory. Energy Convers. Manag. 117, 501-512. doi:10.1016/j.enconman.2016.03.048

Tiwari, G.N., Sahota, L., 2017. Review on the energy and economic efficiencies of passive and active solar distillation systems. Desalination 401, 151-179. doi:10.1016/j.desal.2016.08.023

Tsakiris, G., Spiliotis, M., Paritsis, S., Alexakis, D., 2009. Assessing the water potential of karstic saline springs by applying a fuzzy approach: The case of Almyros (Heraklion, Crete). Desalination 237, 54-64. doi:10.1016/j.desal.2007.12.022

Velmurugan, V., Deenadayalan, C.K., Vinod, H., Srithar, K., 2008a. Desalination of effluent using fin type solar still. Energy 33, 1719-1727. doi:10.1016/j.energy.2008.07.001

Velmurugan, V., Gopalakrishnan, M., Raghu, R., Srithar, K., 2008b. Single basin solar still with fin for enhancing productivity. Energy Convers. Manag. 49, 2602-2608. doi:10.1016/j.enconman.2008.05.010

Velmurugan, V., Naveen Kumar, K.J., Noorul Haq, T., Srithar, K., 2009. Performance analysis in stepped solar still for effluent desalination. Energy 34, 1179-1186. doi:10.1016/j.energy.2009.04.029

Velmurugan, V., Srithar, K., 2011. Performance analysis of solar stills based on various factors affecting the productivity - A review. Renew. Sustain. Energy Rev. doi:10.1016/j.rser.2010.10.012

Velmurugan, V., Srithar, K., 2007. Solar stills integrated with a mini solar pond - analytical simulation and experimental validation. Desalination 216, 232-241. doi:10.1016/j.desal.2006.12.012

Voropoulos, K., Mathioulakis, E., Belessiotis, V., 2001. Experimental investigation of a solar still coupled with solar collectors. Desalination 138, 103-110. doi:10.1016/S00119164(01)00251-X

Wang, C.C., 2011. On the heat transfer correlation for membrane distillation. Energy Convers. Manag. 52, 1968-1973. doi:10.1016/j.enconman.2010.11.014

Yadav, S., Sudhakar, K., 2015. Different domestic designs of solar stills: A review. Renew. Sustain. Energy Rev. 47, 718-731. doi:10.1016/j.rser.2015.03.064

Yetilmezsoy, K., Abdul-Wahab, S.A., 2014. A composite desirability function-based modeling approach in predicting mass condensate flux of condenser in seawater greenhouse. 
Desalination 344, 171-180. doi:10.1016/j.desal.2014.03.029

Yu, Z., Dexter, A., 2010. Hierarchical fuzzy control of low-energy building systems. Sol. Energy 84, 538-548. doi:10.1016/j.solener.2009.03.014

Zhang, Y., Peng, Y., Ji, S., Li, Z., Chen, P., 2015. Review of thermal efficiency and heat recycling in membrane distillation processes. Desalination. doi:10.1016/j.desal.2015.04.013

Zilouchian, A., Jafar, M., 2001. Automation and process control of reverse osmosis plants using soft computing methodologies. Desalination 135, 51-59. doi:10.1016/S00119164(01)00138-2

\section{List of Tables}

Table 1 Five point scale for various input and output criteria

Table 2 Triangular fuzzy (TFN) scale and its inverse TFN scale

Table 3 Demographic details of the experts

Table 4 CR value for the input and output criteria

Table 5 Pairwise comparison

Table 6 Comparing the values of fuzzy synthetic extent

Table 7 Fuzzy AHP weights for Input criteria

Table 8 Upper and lower bounds of weights input criteria

Table 9 Fuzzy AHP weights for output criteria

Table 10 Upper and lower bounds of weights output criteria

Table 11 Input/output criteria for 20 solar stills

Table 12 Weight distribution of AR-CCR (with weight restriction)

Table 13 Efficiency and rank of solar stills 


\section{List of Figures}

Fig. 1. Detailed tabulation showing classification of desalination processes (Nayi and Modi, 2018)

Fig. 2. Various types of solar stills (Tiwari and Sahota, 2017)

Fig. 3. Various climate, design and operational parameters influencing the productivity of solar still (Muftah et al., 2014)

Fig. 4. Setup of simple single slope solar still (Ali Samee et al., 2007)

Fig. 5. Schematic of solar still with sun tracking system (Abdallah et al., 2008)

Fig. 6. Solar still integrated with photo-voltaic thermal (PVT) system (Kumar and Tiwari, 2009)

Fig. 7. Solar still integrated with flat-plate collector (Badran and Al-Tahaineh, 2005)

Fig. 8. Schematic of solar still integrated with concentrators (Abdel-Rehim and Lasheen, 2007)

Fig. 9. Schematic setup of solar still integrated with fin (Velmurugan et al., 2008a)

Fig. 10. Pictorial representation of hemispherical solar still (Ismail, 2009)

Fig. 11. Schematic configuration of pyramid type solar still (Fath et al., 2003)

Fig. 12. Schematic of solar still with sponge (Velmurugan et al., 2008b)

Fig. 13. Solar still with phase change material (PCM) (Shalaby et al., 2016)

Fig. 14. Overall methodology of integrated fuzzy AHP DEA

Fig. 15. Hierarchical structure of various input and output criteria used in DEA

Fig. 16. Input/output criteria for the twenty solar stills

Fig. 17. Efficiency decomposition of twenty solar stills 


\title{
Techno-economic analysis of solar stills using integrated fuzzy analytical hierarchy process
} and data envelopment analysis

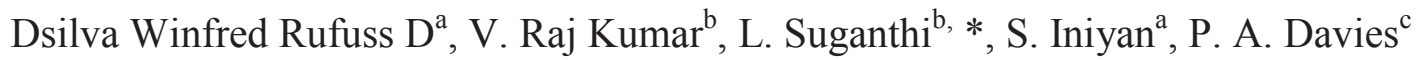

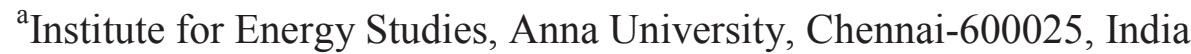 \\ ${ }^{b}$ Department of Management Studies, College of Engineering Guindy, Anna University, \\ Chennai-600025, India
}

${ }^{\mathrm{c}}$ Sustainable Environment Research Group, School of Engineering and Applied Science, Aston University, Birmingham, B4 7ET, UK

*Corresponding author: suganthi_au@yahoo.com

\begin{abstract}
Desalination using solar stills is an ancient economic method for water desalination. Over the years, research and development in the area of solar still has resulted in increased distillate yield by means of integration of PCM (phase change material), photo-voltaic thermal (PVT), etc with the still. Nano-PCM is an upcoming technology which modifies the thermal performance of PCM. The aim of this research is to analyze the efficiency of 20 solar stills including nano-PCM based solar stills considering various input and output criteria using integrated fuzzy analytical hierarchy process (AHP) and data envelopment analysis (DEA). The efficiency derived here is relative with regard to the parameters and stills considered in this study. The result infers that, even though the productivity of stepped solar still with sun tracking system was high, but when techno-economic aspects were considered it is not among the top solar stills. The analysis indicated pyramid type solar still, single slope solar still with PVT, solar still with NPCM (paraffin + copper oxide), solar still with NPCM (paraffin + titanium dioxide) and solar still with PCM (paraffin) occupies the top five positions with relative efficiency of 100, 100, 88.47, 88.46 and $76.93 \%$ respectively.
\end{abstract}

\section{Keywords}

Solar stills; Fuzzy AHP DEA; Relative efficiency; MCDM

\section{Introduction}

Solar desalination is a type of desalination process in which evaporation and condensation processes are driven by solar energy. Among the various types of solar desalination processes, solar stills are significant because of their low environmental impact, technical simplicity, low capital and maintenance cost (Dsilva Winfred Rufuss et al., 2016). Solar still can be used in extremely adverse environments, where there is no source of power for running the otherwise efficient desalination process (Dsilva Winfred Rufuss et al., 2016). Various researchers have modified the conventional solar still to improve its productivity. However this led to an increase in capital and maintenance cost. Studies carried out by earlier researchers (El-Bialy et al., 2016; Kabeel et al., 2010) determined the various costs of solar stills. However, there is no study found in the literature review so far which presents an optimized multi-criteria decision model (MCDM) that considers various criteria such as cost, employee's skill, productivity and technical 
features of solar stills. These aspects need to be considered to ascertain the importance of each criteria for the selection of an ideal solar still that can be taken up for commercialization. This paper focuses on the MCDM approach to analyze the relative efficiency of solar stills based on various input and output criteria using an integrated fuzzy AHP model.

There are various criteria / parameters influencing a solar still such as atmospheric condition, design and economics. Atmospheric condition includes weather, ambient temperature, location, and latitude / longitude degrees. The design aspect includes area, glass cover inclination, brine depth, solar intensity, productivity, salt concentration and insulators. Economic aspects include present capital cost, annual maintenance/ operational cost, annual salvage value and cost of distilled water per litre. Hence selection of a solar still for commercialization needs to be done by considering such parameters as mentioned above. In this paper, fuzzy analytical hierarchy process (AHP) and data envelopment analysis (DEA) techniques are used to optimize some of the above mentioned parameters to arrive at an efficiency for each still relative to the parameters considered. Generally, technical (thermodynamic) efficiency will be used in the comparison of solar stills which considers only the technical aspects. In this study in addition to technical aspects other parameters are considered and the efficiency is obtained relative to the parameters and the stills considered. Technical efficiency is an absolute efficiency that can be compared across various stills while relative efficiency is constrained within the parameters used and the stills used in the study.

Many researchers have used fuzzy AHP techniques in desalination systems like multi-stage desalination (MSD), reverse osmosis (RO), multi-stage flash desalination (MSF), vapor compression (VC) and multi-effect distillation (MED). Fuzzy logic was used in controlling the upper saline water temperature of MSD plants. The research also focused on controlling various parameters for implementing MSD plants in the selected location (Ismail, 1998). Various operational constraints was adopted for implementing a RO desalination plant using fuzzy logic. The proposed methodology resulted in profit for the plant by increasing the availability and decreasing the manpower requirement for RO implementation (Zilouchian and Jafar, 2001). Fuzzy logic was adopted for analyzing MSF and RO systems using various control parameters like brine salinity, pre-heating (Gambier and Badreddin, 2003). Water potential was assessed for irrigation and human consumption using fuzzy logic. It was found that the water used for irrigation is more important than for human consumption (Tsakiris et al., 2009). Major factors which affect the daily productivity of solar still was analyzed using fuzzy logic (Mamlook and Badran, 2007). The same authors (Mamlook and Al-Rawajfeh, 2008) extended the research by using fuzzy logic to analyze which of those factors affect the productivity of MED. The various factors considered in their research included top saline water temperature, $\mathrm{pH}$, temperature and salinity of the sea water. The AHP was used to determine the most suitable desalination process considering seven factors. The desalination processes considered in the research include MSD, MSF, RO and VC. The factors considered were water quality, recovery ratio, consumption of energy, efficiency of instruments and total cost (Hajeeh and Al-Othman, 2005). Various water conservation policies in Kuwait was analyzed using fuzzy AHP. Reusing treated brine water, promoting water conservation were some of their recommendations (Hajeeh, 2010). It is found from the literature that researchers have used fuzzy (Gambier and Badreddin, 2003; Ismail, 1998; Mamlook and Al-Rawajfeh, 2008; Mamlook and Badran, 2007; Tsakiris et al., 2009; Zilouchian 
and Jafar, 2001), AHP (Hajeeh and Al-Othman, 2005), fuzzy AHP (Hajeeh, 2010) in desalination systems.

Integrated fuzzy AHP DEA approach can be used in energy related areas like solar photovoltaic, solar thermal, wind, desalination, power stations, materials and metallurgical applications to determine the weights of influencing parameters and to find the relative efficiency among a set of energy systems. Some researchers used fuzzy for finding the efficiency frontier in petrochemical industries (Taylan et al., 2016), generation sector (Mojallizadeh and Badamchizadeh, 2017; Tanha Aminloei and Ghaderi, 2010; Yu and Dexter, 2010). AHP was used for categorizing frontier energy industries in manufacturing sector (Jovanović et al., 2015) and integrated fuzzy AHP DEA approach has been used (Criswell and Thompson, 1996; Lee et al., 2013, 2011) for finding the relative efficiency of energy technology and hydrogen energy technologies.

Fuzzy logic helps in arriving at concrete estimates despite the vagueness of human thought. AHP helps in obtaining the relative weights for a set of critical attributes. The benefits of integrating fuzzy logic and AHP is to achieve precision in determining the relative importance of criteria and to develop a hierarchal structure for the multi-criteria decision making purpose. It can handle both linguistic assignment and numerical values. The benefits of applying an integrated fuzzy AHP approach to solar still is to determine the relative importance/weights of criteria that affects the performance and efficiency of solar still. DEA is a benchmarking technique employed to know the frontier in the selected area by estimating the relative efficiency of various decision making units (DMU). The benefits of integrating fuzzy AHP and DEA are to find the relative efficiency of DMU considering the weights of criteria obtained from fuzzy AHP. The advantage of implementing such an approach in solar still is to rank and prioritize the important criteria which is involved in the performance, efficiency and productivity of a solar still. Also, the relative efficiency of various solar stills by considering both technical and economic factors can be determined by giving due importance to the influencing criteria. The main objective of other techno-economic analysis (TEA) such as top-down or bottom-up cost approach is to determine the cost and technical feasibility of a particular system (here solar still) and compare the results. In this paper, the integrated approach (fuzzy AHP DEA) is a step ahead i.e., it helps to evaluate the relative efficiency of various solar stills considering several criteria simultaneously to arrive at an optimal decision. The pros of the integrated fuzzy AHP DEA are: comparative analysis of different variant of targets (here solar stills), any measurable criteria for all variant of solar still can be used in DEA, reverse coding of input and output criteria is possible, improvement criteria for the selected parameters can be identified and implemented, human preference can also be incorporated in DEA and fuzzy AHP DEA can be incorporated as a complement to other techniques. As every approaches have some cons associated with them, similarly this integrated fuzzy AHP DEA also has some cons such as: difficulty arises if there is a missing value in the dataset and weak assumption in DEA may lead to underestimation of the relative efficiency of decision making units.

Further, this integrated fuzzy AHP DEA approach can also be used in other energy-related areas including solar photovoltaic, solar thermal, wind, desalination, power stations, materials and metallurgical applications to determine the weights of influencing parameters and to find the relative efficiency among a set of energy systems. It is concluded that, even though various 
researchers used fuzzy and AHP techniques in desalination systems, no one has used an integrated fuzzy-AHP-DEA analysis for analysing the different solar stills. Hence this research gap is addressed in this paper in addition to analyzing the innovative nano-PCM based solar stills from a techno-economic viewpoint. Nanoparticles were incorporated with PCM to modify its thermal properties like thermal conductivity, latent heat of vaporization and decreasing its charging and discharging rate (Dsilva Winfred Rufuss et al., 2017; Kamaraj et al., 2016). Even though nanoparticles improve the thermal properties of PCM in solar still, economic feasibility of the solar still with nano-PCM is one of the essential parameter that needs to be analyzed. Three input criteria namely fabrication/installation cost, skilled labour requirement and land area requirement are considered along with four output criteria namely annual cost, commercial potential, annual productivity and technical complexity. An integrated fuzzy-AHP-DEA analysis is carried out to determine the relative efficiencies of 20 solar stills (for which the data is available for the parameters considered). Also, the relative weights of each criteria and their importance with reference to a particular still are determined.

\section{Solar stills}

Desalination is an essential response to the growing water scarcity problem. It has been reported in our previous paper (Dsilva Winfred Rufuss et al., 2016) that, by the year 2030 half of the world population will experience severe water crisis. There are various desalination process available to desalinate the saline water, of which solar still holds its significance owing to its enviro-economic friendly nature (Kaushal and Varun, 2010; Sathyamurthy et al., 2017; Velmurugan and Srithar, 2011). Solar stills work by the evaporation and condensation processes similar to natural rain. A detailed classification of the desalination process and solar stills are represented graphically in Fig. 1 and Fig. 2 respectively. Low productivity is a major drawback in solar stills, and hence extensive research work has been carried to improve the productivity by modifying the design and operational parameters (Ahsan et al., 2012; Arunkumar et al., 2013, 2012; Gaur and Tiwari, 2010; Murugavel et al., 2010; Rahbar et al., 2016; Sakthivel et al., 2010; Sharshir et al., 2016). The various design and operational parameters are comprehensively listed in Fig. 3.

The basic model of solar still is called a simple single slope solar still. This does not have any enhancements present for augmenting the productivity. The setup of simple single slope solar still is depicted in Fig. 4.

Insert Fig. 1. Detailed tabulation showing classification of desalination processes (Nayi and Modi, 2018)

Insert Fig. 2. Various types of solar stills (Tiwari and Sahota, 2017)

Insert Fig. 3. Various climate, design and operational parameters influencing the productivity of solar still (Muftah et al., 2014)

Insert Fig. 4. Setup of simple single slope solar still (Ali Samee et al., 2007)

Researchers tried to add various components like sun tracker (Abdallah et al., 2008), photovoltaic-thermal (PVT) (Kumar and Tiwari, 2009), collector (Badran and Al-Tahaineh, 2005), 
concentrator (Abdel-Rehim and Lasheen, 2007) and fin (Velmurugan et al., 2008a) to improve the productivity. This resulted in changes in other parameters also namely fabrication cost, skill level of labourers required to construct the solar still, complexity, land area requirement. The pictorial representations of solar stills with sun tracker, PVT, collector, concentrator and fin are depicted in Fig. 5, Fig. 6, Fig. 7, Fig. 8 and Fig. 9 respectively.

Insert Fig. 5. Schematic of solar still with sun tracking system (Abdallah et al., 2008)

Insert Fig. 6. Solar still integrated with photo-voltaic thermal (PVT) system (Kumar and Tiwari, 2009)

Insert Fig. 7. Solar still integrated with flat-plate collector (Badran and Al-Tahaineh, 2005)

Insert Fig. 8. Schematic of solar still integrated with concentrators (Abdel-Rehim and Lasheen, 2007)

Insert Fig. 9. Schematic setup of solar still integrated with fin (Velmurugan et al., 2008a)

Some researchers tried to modify the whole design of the solar still with unconventional shapes i.e, hemispherical (Ismail, 2009) and pyramid shapes (Fath et al., 2003). The design setup of hemispherical and pyramid solar still is depicted in Fig. 10 and Fig. 11 respectively. These modifications resulted in increasing the technical complexity and skilled labour required for fabrication, erection and maintenance and decreased the land area requirement as compared to conventional solar stills.

Insert Fig. 10. Pictorial representation of hemispherical solar still (Ismail, 2009)

Insert Fig. 11. Schematic configuration of pyramid type solar still (Fath et al., 2003)

The energy storage experts tried to integrate energy storage in solar still applications using wick, sponge (Velmurugan et al., 2008b), phase change materials (Shalaby et al., 2016) was integrated to solar stills to enhance the productivity. The solar still with wick, sponge and phase change materials are depicted in Fig. 12 and Fig. 13 respectively. This type of integration has no change on the land area requirement and has a slight increase on other factors like technical complexity, fabrication cost. In recent years, researchers have tried using nanoparticle impregnation in PCM for solar still applications. It was inferred from the literature that the impregnation of nanoparticles in PCM may either improve or impair the thermal properties of the base material (Dsilva Winfred Rufuss et al., 2017; Rao Nulakani et al., 2015).

As stated earlier these kinds of modifications end up with an increase in fabrication cost, technical complexity and skilled labour. Hence there is a need to identify a still with optimum factors. The criteria measured before the fabrication of solar stills are considered as input criteria and the criteria involved in the commercialization are considered as output criteria. In this research skilled labour requirement (SL), fabrication and installation cost (FC) and land area requirement (LA) are considered as the input criteria while economic impact (EI), commercial potential (CP), productivity (P) and technical complexity (TC) are considered as the output 
criteria for the integrated fuzzy analytical hierarchy process. The analysis will help us to determine the unique contribution with respect to a certain criteria as well as its relative importance vis-à-vis other criteria. The traditional top down or bottom up approaches for technoeconomic analysis will only present the overall cost comparison among the solar stills while the present analysis will clearly highlight how concentration on a specific input criteria will improve the overall efficiency of a solar still as well as the efficiency for each of the output criteria.

Insert Fig. 12. Schematic of solar still with sponge (Velmurugan et al., 2008b)

Insert Fig. 13. Solar still with phase change material (PCM) (Shalaby et al., 2016)

\section{Methodology}

The empirical analysis is carried out by collecting various quantitative data on the input/output criteria of the solar still. In this research, fabrication costs (FC) for the 16 solar stills are taken from the literature (Abdallah et al., 2008; Abdallah and Badran, 2008; Abdel-Rehim and Lasheen, 2007; Ali Samee et al., 2007; Badran et al., 2005; Badran and Al-Tahaineh, 2005; ElBahi and Inan, 1999; El-Bialy et al., 2016; El-Sebaii et al., 2008; Fath et al., 2003; Ismail, 2009; Kabeel et al., 2010; Kumar and Tiwari, 2009; Velmurugan et al., 2009, 2008a, 2008b; Velmurugan and Srithar, 2007; Voropoulos et al., 2001) while for the remaining four stills Solar stills with PCM, Nano PCM namely titanium dioxide, copper oxide, graphene oxide, data is obtained from the investigation carried out using the experimental setup in the Institute for Energy Studies, Anna University Chennai, India (Dsilva Winfred Rufuss et al., 2017; Rufuss et al., 2015). The various scales for the input/output criteria such as SL, LA, EI, CP, P and TC are tabulated in Table.1. The overall methodology adopted in the study using this integrated approach is clearly depicted in Fig. 14.

Insert Table 1 Five point scale for various input and output criteria

Insert Fig. 14. Overall methodology of integrated fuzzy AHP DEA

\subsection{Applying the Fuzzy AHP method}

AHP helps in finding the importance of criteria as a hierarchical structure. Experts were identified based on their domain knowledge in the field of renewable energy with special reference to solar energy and solar stills. They were asked to give the relative ratings for pairwise comparisons of the criteria. The consistency of each expert is determined as follows (Lee et al., 2013, 2011; Tanha Aminloei and Ghaderi, 2010; Taylan et al., 2016):

$$
\mathrm{CI}=\frac{\lambda_{\max }-\mathrm{n}}{\mathrm{n}-1}
$$

where $\lambda_{\max }$ and $\mathrm{n}$ are the principal eigenvalue and dimension of the matrix. The pairwise comparison is accepted only if the $\mathrm{CR} \leq 0.10$. Consistency ratio (CR) is the ratio of consistency index $(\mathrm{CI})$ to random index $(\mathrm{RI})[14,15]$. 


$$
\mathrm{CR}=\frac{\mathrm{CI}}{\mathrm{RI}}
$$

The analysis is repeated for each expert for the input and output criteria. Though AHP captures the preference of expert, fuzzy AHP is used to determine the priority weights of the input and output criteria using hierarchical fuzzy decision making process.

The triangular fuzzy scale (TFN) and the inverse scale are given in Table 2.

Insert Table 2 Triangular fuzzy (TFN) scale and its inverse TFN scale

Let $\quad M_{i j}=\left(l_{i j}, m_{i j}, u_{i j}\right)$

$\mathrm{M}_{\mathrm{ij}}$ be the TFN for a fuzzy pair wise comparison judgment, where $1, \mathrm{~m}$ and $\mathrm{u}$ are lower, mid and upper limit respectively.

The synthetic extent value with respect to $i^{\text {th }}$ object is calculated using the following formulas $[14,15]$

$$
\begin{gathered}
S_{i}=\sum_{j=1}^{m} M_{i j}\left[\sum_{i=1}^{n} \sum_{j=1}^{m} M_{i j}\right]^{-1} \\
\sum_{j=1}^{m} M_{i j}=\left(\sum_{j=1}^{m} l_{i j}, \sum_{j=1}^{m} m_{i j}, \sum_{j=1}^{m} u_{i j}\right), i=1,2,3,4, \ldots, n \\
\sum_{i=1}^{n} \sum_{j=1}^{m} M_{i j}=\left(\sum_{i=1}^{n} \sum_{j=1}^{m} l_{i j}, \sum_{i=1}^{n} \sum_{j=1}^{m} m_{i j}, \sum_{i=1}^{n} \sum_{j=1}^{m} u_{i j}\right) \\
{\left[\sum_{i=1}^{n} \sum_{j=1}^{m} M_{i j}\right]^{-1}=\left(\frac{1}{\sum_{i=1}^{n} \sum_{j=1}^{m} u_{i j}}, \frac{1}{\sum_{i=1}^{n} \sum_{j=1}^{m} m_{i j}}, \frac{1}{\sum_{i=1}^{n} \sum_{j=1}^{m} l_{i j}}\right)}
\end{gathered}
$$

The value of $S_{i}$ is then determined and the degree of possibility of $S_{j}=\left(l_{j}, m_{j}, u_{j}\right) \geq S_{i}=\left(l_{i}, m_{i}, u_{i}\right)$ is expressed by the following equation $[14,15]$.

$$
V\left(S_{j} \geq S_{i}\right)=\operatorname{height}\left(S_{i} \cap S_{j}\right)=u_{s_{j}}(d)= \begin{cases}1, & \text { if } m_{j} \geq m_{i} \\ 0, & \text { if } l_{i} \geq u_{j} \\ \frac{l_{i}-u_{j}}{\left(m_{j}-u_{j}\right)-\left(m_{i}-l_{i}\right)}, & \text { otherwise }\end{cases}
$$

The minimum degree of possibility $d^{\prime}$ (i) of $V\left(S_{i} \geq S_{j}\right)$ for $i=1,2,3, . ., k$ and $j=1,2,3, . ., k$ is calculated using $[14,15]$

$$
\begin{gathered}
\mathrm{V}\left(\mathrm{S} \geq \mathrm{S}_{1}, \mathrm{~S}_{2}, \ldots, \mathrm{S}_{\mathrm{k}}\right) \text { for } \mathrm{i}=1,2, \ldots, \mathrm{k}=\mathrm{V}\left[\left(\mathrm{S} \geq \mathrm{S}_{1}\right) \operatorname{and}\left(\mathrm{S} \geq \mathrm{S}_{2}\right) \text { and.. }\left(\mathrm{S} \geq \mathrm{S}_{\mathrm{k}}\right)\right] \\
=\min \mathrm{V}\left(\mathrm{S} \geq \mathrm{S}_{\mathrm{i}}\right) \text { for } \mathrm{i}=1,2, \ldots, \mathrm{k}
\end{gathered}
$$




$$
\text { Assume } d^{\prime}\left(A_{i}\right)=\min V\left(S \geq S_{i}\right) \text { for } 1=12, \ldots, k
$$

The weight vector is found using the equation $[14,15]$

$$
W^{\prime}=\left(d^{\prime}\left(A_{1}\right), d^{\prime}\left(A_{2}\right), \ldots, d^{\prime}\left(A_{n}\right)\right)^{T} \text { where } A_{i}(i=1,2,3,4, \ldots, n) \text { are the } n \text { elements }
$$

The weight vectors are then normalized to get the relative weight using the formula $[14,15]$

$$
W=\left(d\left(A_{1}\right), d\left(A_{2}\right), \ldots, d\left(A_{n}\right)\right)^{T}
$$

where $\mathrm{W}$ is a non-fuzzy number indicating the relative weight of the criteria.

\subsection{Measuring the relative efficiency using DEA}

The relative efficiency of various types of solar still is calculated by using DEA approach. Fig. 15 , shows the hierarchy of the DEA process which consist of three input and four output criteria. DEA is an analytical technique used to determine the efficient utilization of resources in a decision making unit (DMU). The model developed by (Charnes et al., 1978) is adopted to find the relative efficiency. The DEA formulation is as follows:

There are $\mathrm{n}$ units with $\mathrm{s}$ outputs denoted by $\mathrm{Y}_{\mathrm{rk}}, \mathrm{r}=1,2, . ., \mathrm{s}$ and $\mathrm{m}$ inputs denoted by $\mathrm{X}_{\mathrm{ik}}$, $\mathrm{i}=1,2, \ldots, \mathrm{m}$, the efficiency score $\left(\mathrm{h}_{\mathrm{k}}\right)$ for the $\mathrm{DMU}_{\mathrm{k}}$

$$
\mathrm{h}_{\mathrm{k}}=\operatorname{Max} \frac{\sum_{\mathrm{r}=1}^{\mathrm{s}} \mathrm{u}_{\mathrm{rk}} \mathrm{Y}_{\mathrm{rk}}}{\sum_{\mathrm{i}=1}^{\mathrm{m}} \mathrm{v}_{\mathrm{ik}} \mathrm{X}_{\mathrm{ik}}}
$$

where $\mathrm{u}_{\mathrm{r}}$ and $\mathrm{v}_{\mathrm{i}}$ are non-negative weights.

In order to obtain the efficiency of DMU in such a manner that they are not greater than 1 , the equations are rewritten as follows:

$$
\begin{gathered}
\text { s.t } \frac{\sum_{\mathrm{r}=1}^{\mathrm{s}} \mathrm{u}_{\mathrm{rk}} \mathrm{Y}_{\mathrm{rk}}}{\sum_{\mathrm{i}=1}^{\mathrm{m}} \mathrm{v}_{\mathrm{ik}} \mathrm{X}_{\mathrm{ik}}} \leq 1, \text { for } \mathrm{j}=1,2,3, \ldots, \mathrm{n} \\
\mathrm{u}_{\mathrm{rk}}>0, \text { for } r=1,2,3, \ldots, s \\
\mathrm{v}_{\mathrm{ik}}>0, \text { for } i=1,2,3, \ldots, m
\end{gathered}
$$

The efficiency ranges between 0 and 1 . The system with maximum efficiency is the system lying in the efficient frontier and is considered to be the best as compared to the other systems. The above equation is transformed to a linear programming problem one for each DMU as follows (Lee et al., 2013, 2011):

$$
\mathrm{h}_{\mathrm{k}}=\max \sum_{\mathrm{r}=1}^{\mathrm{s}} \mathrm{u}_{\mathrm{r}} \mathrm{Y}_{\mathrm{rk}}
$$




$$
\begin{aligned}
& \text { s.t } \sum_{i=1}^{m} v_{i} X_{i j}- \sum_{r=1}^{s} u_{r} Y_{r j} \geq 0 \text { for } j=1,2,3, \ldots, n \\
& \sum_{i=1}^{m} v_{i} X_{i k}=1 \\
& u_{r} \geq 0 \text { for } r=1,2,3, \ldots, s(19) \\
& v_{i} \geq 0 \text { for } i=1,2,3, \ldots, m
\end{aligned}
$$

Insert Fig. 15. Hierarchical structure of various input and output criteria used in DEA

The model obtained is referred to as the CCR model. This CCR model assumes that the production components are constant return-to-scale. Assurance region (AR) is selected to avoid null outputs in the analysis. In AR-CCR model, a set of new constrains will be included in the above model in such a way that the weights are restricted with a lower and upper bound.

$$
\mathrm{L}_{1,2} \leq \frac{\mathrm{u}_{\mathrm{j} 1}}{\mathrm{u}_{\mathrm{j} 2}} \leq \mathrm{U}_{1,2}
$$

where $L_{1,2}$ and $U_{1,2}$ are lower and upper bound. $\mathrm{u}_{\mathrm{j} 1}$ and $\mathrm{u}_{\mathrm{j} 2}$ present the weight achieved by the $\mathrm{DMU}_{\mathrm{j}}$. By adding equation 21 in the CCR model, AR-CCR model is obtained.

\section{Results and discussion}

Researchers have been working in various types of solar still and have identified several technically viable stills. However, for a still to be made commercially viable we need to study the social and economic aspects in addition to technical aspects. Such a study which integrates energy production and energy efficiency parameters across various energy systems from a techno-economic viewpoint needs to be done to obtain a realistic estimate of an energy system. In this study, energy production parameters namely productivity, commercial potential; energy efficiency parameters namely technical complexity; economic parameters namely fabrication and maintenance costs; social parameters namely employee skill level, land area have been considered and studied in the MCDM analysis.

\subsection{Fuzzy AHP DEA approach}

Experts were chosen based on their teaching, research and industrial experience in the domain area namely renewable energy, desalination and solar stills. The choice of the number of experts depend on the availability of the experts and their accessibility. There is no literature available which specifies the number of experts to be chosen for AHP based decision making process (Nixon et al., 2010). The outcome varies as the expert size varies since, greater the number of experts, arriving at a consensus becomes complex due to the uncertainty in the decision making process. The judgement of the experts should have minimum variability with high level of confidence and convergence. In general practice, literatures indicate that smaller expert size kindles effective impact and involvement which lead to the group unanimity (Dey, 2004; Nixon 
et al., 2010). The consistency ratio of the experts was found and the response of 10 experts was then used for further analysis. The demographic details of the experts are given in Table 3.

Insert Table 3 Demographic details of the experts

The experts were asked to rank the relative importance of the various input and output criteria using AHP relative importance scale. Using the relative importance score given by the experts, the CR for each expert was determined for each of the input/output criteria and the values are tabulated in Table 4. From the Table 4, it is found that the CR value for all the ten experts are less than 0.1 . Hence all the experts' opinion are considered valid and used for further analysis. The synthetic weight was then determined for the input and output criteria for each of the expert. The procedure adopted is presented for one expert for the input criteria. This procedure is repeated for all the experts as well as for the output criteria. The pairwise comparison of TFN value of one expert (expert-1) using Table 2 is shown in Table 5.

Insert Table $4 \mathrm{CR}$ value for the input and output criteria

Insert Table 5 Pairwise comparison

Using the equation (4), (5), (6) and (7), the synthetic weights are obtained as follows.

$$
\begin{aligned}
& S_{1}(S L)=(3,3.666,4.5) \otimes\left(\frac{1}{12.333}, \frac{1}{10.166}, \frac{1}{8.3}\right) \\
& S_{2}(F C)=(1.8,2,2.33) \otimes\left(\frac{1}{12.33}, \frac{1}{10.166}, \frac{1}{8.3}\right) \\
& S_{3}(L A)=(3.5,4.5,5.5) \otimes\left(\frac{1}{12.33}, \frac{1}{10.166}, \frac{1}{8.3}\right)
\end{aligned}
$$

The degree of possibility $\mathrm{S}_{\mathrm{j}}$ (equation 8 ) is given in Table 6.

Insert Table 6 Comparing the values of fuzzy synthetic extent

The minimum degree of possibility d' (i) found using equation 9 is as follows:

$\mathrm{d}^{\prime}(1)=\min \mathrm{V}\left(\mathrm{S}_{1} \geq \mathrm{S}_{2}, \mathrm{~S}_{3}\right)=0.7591$

$\mathrm{d}^{\prime}(2)=\min \mathrm{V}\left(\mathrm{S}_{2} \geq \mathrm{S}_{1}, \mathrm{~S}_{3}\right)=0$

$\mathrm{d}^{\prime}(3)=\min \mathrm{V}\left(\mathrm{S}_{3} \geq \mathrm{S}_{1}, \mathrm{~S}_{2}\right)=1$

Using equation 10, the weight vector is determined and their relative weights are shown below

$\mathrm{W}^{\prime}=(0.7591,0,1)^{\mathrm{T}}$

Hence the relative weights are

$\mathrm{W}=(0.43155,0,0.56845)^{\mathrm{T}}$ 
The same procedure is repeated for each of the ten experts and the weights are listed in Table 7. The lower and upper bound is calculated by considering the minimum and maximum values of the weights. These weights are then incorporated in Charnes, Cooper, Rhodes (CCR) model. The upper and lower bounds for the input criteria are tabulated in Table 8. Similarly the weights of ten experts are determined for the output criteria and the values are presented in Table 9. Also, the lower bound and the upper bound values are obtained for the output criteria and the corresponding values are tabulated in Table 10. The quantitative data used in the analysis for the 20 stills is presented in Table 11 and the radar chart depicting their input/output criteria is represented in Fig. 16. From the radar chart, it is clear that certain solar stills (such as still with wick, hemispherical solar still, stepped still, weir type still, still with collector, concentrator and fin), should improve its commercial potential and productivity or reduce their fabrication cost to reach the top position. The data is normalized and used for further analysis. DEA model is run using the add-in package available in Microsoft Excel. The weight distribution of AR-CCR (with weight restriction) for the 20 stills is shown in Table 12.

Insert Table 7 Fuzzy AHP weights for Input criteria

Insert Table 8 Upper and lower bounds of weights input criteria

Insert Table 9 Fuzzy AHP weights for output criteria

Insert Table 10 Upper and lower bounds of weights output criteria

Insert Table 11 Input/output criteria for 20 solar stills

Insert Table 12 Weight distribution of AR-CCR (with weight restriction)

Insert Fig. 16. Input/output criteria for the twenty solar stills

Here the various stills are considered as decision making units. The productive efficiency decomposition of the various DMU's (in this case, various solar stills) is obtained from the ARCCR model and given in Table 13. The efficiency decomposition of twenty solar stills is depicted in Fig. 17. For the solar still with wick and fin to be on the frontier, it is necessary to reduce the skilled labour requirement or increase its economic impact. For a transportable hemispherical solar still to reach the efficiency frontier, we should reduce its fabrication cost and land area requirement. In the case of solar still with wick and sponge, we should improve its commercial potential and technical complexity. In the case of the stepped solar still with sun tracking system, we should reduce its fabrication cost, skilled labour requirement and improve its economic impact. For a weir type solar still, we should focus on improving its economic impact and productivity. The solar still with sponge \& pond, shallow pond and condenser require improvements in their economic impact and productivity or reduce their fabrication cost and land area requirement. For the solar still with collector and concentrator, we should either reduce its technical complexity and skilled labour requirement or improve its economic impact and commercial potential. Pyramid type solar stills should improve its commercial potential, economic impact and productivity. In the case of solar still with PCM and nano-PCM's, it is important to reduce fabrication cost and skilled labour requirement or improve its economic impact and commercial potential to reach the efficiency frontier. 
Insert Fig. 17. Efficiency decomposition of twenty solar stills

When the efficiency of a solar still is $1.00(100 \%)$, then that particular solar still is in the efficiency frontier and is considered to be the most efficient solar still considering all the input and output criteria. From the DEA results, a pyramid type solar still and single slope solar still with PVT lies in the efficiency frontier and are the most efficient solar stills. Solar still with Nano PCM (Copper oxide) and solar still with Nano PCM (Titanium dioxide) come next with the efficiency of 0.8847 and 0.8846 respectively. Solar still with graphene oxide, though technically the best solar still (Dsilva Winfred Rufuss et al., 2016; Rufuss et al., 2015), is completely ruled out since its efficiency is only 0.487 . In the case of NPCM based solar still (solar still with copper oxide and titanium dioxide) [ranked no.3 and 4] to reach the efficiency frontier there is $12 \%$ lag. Solar still with copper oxide needs to either decrease its skilled labour requirement or increase its economic impact / commercial potential to become the most efficient solar still. Similarly for solar still with titanium dioxide to improve its efficiency position, research has to be done to improve its economic impact and commercial potential.

To summarize, among the various types of solar still technologies, the top five stills which are both technically and economically efficient are pyramid type solar still, single slope solar still with PVT, solar still with NPCM (copper oxide), solar still with NPCM (titanium dioxide) and solar still with PCM. The remaining stills are either technically strong or economically strong. For example, transportable hemispherical solar still and stepped solar still with sun tracking system are technically strong, but when we consider both technical and economic aspects, it is not found among the best solar still technologies. In general, it is recommended that the relative efficiency of solar stills can be enhanced either by decreasing the cost of skilled labour (SL), fabrication (FC), and land area requirement (LA) or by increasing its economic impact (EI), commercial potential (CP), productivity $(\mathrm{P})$ and technical complexity (TC). Hence future research and development in solar stills must be carried out by considering both technical and economic aspects for effective commercialization of solar still technology.

\subsection{Applications and recommendation for future works}

This techno-economic approach to solar stills will be useful for industrialist to identify the pros and cons of various solar stills. It will help them to select a solar still based on their indigenous resource availability and their strengths. For example, if there is a policy initiative to give a $50 \%$ subsidy towards fabrication, then the ranking of stills will undergo a change i.e., pyramid type solar still will take a lead role followed by solar still with NPCM, solar still with pond, and then solar still with PCM. Thus either by increasing the level of the output criteria like productivity, economic impact or decreasing the level of input criteria such as capital cost, labour, efficiency of the energy system can be improved. The values of each parameter in the decomposition table indicates areas where a certain stills can be improved to make it competitive and to reach the efficiency frontier. This integrated fuzzy AHP DEA approach can be used in other desalination system to find the relative efficiency of desalination processes like multi-effect flash distillation (Baig et al., 2011; Choi, 2016; Elzahaby et al., 2016), membrane distillation (Nakoa et al., 2015; Orfi et al., 2016; Wang, 2011; Zhang et al., 2015), FO \& RO(forward and reverse osmosis) 
(Altaee and Hilal, 2015; Delgado-Torres and García-Rodríguez, 2010; Khanzada et al., 2017; Mokheimer et al., 2013; Mudgal and Davies, 2016; Qasim et al., 2015), ion exchange (AlMarzooqi et al., 2014; Hilal et al., 2015a, 2015b), seawater greenhouse techniques (Davies et al., 2004, 2006; Davies and Knowles, 2006; Davies and Paton, 2005; Yetilmezsoy and AbdulWahab, 2014), etc. by selecting the techno-economic input/output parameters.

This integrated approach can also be employed in other applications like renewable energy sectors (solar, wind, tidal, biomass, etc.) and power generation sectors (conventional and nonconventional power plants). In the renewable energy sector, this approach can be used to determine the energy production efficiency in solar and wind. In solar, the relative efficiency of energy production can be investigated by considering various input/output parameters like capacity, location, demand, complexity, land area requirement, etc. for various solar cells such as crystalline silicon solar cell, hybrid solar cell, gallium arsenide solar cell, polymer solar cell, and solid-state solar cell. The energy production and energy efficiency in the wind energy sector can be analyzed using this integrated fuzzy AHP DEA approach by considering input/output parameters like turbine capacity, tower height, power production, land and location, number of blades for various types of wind turbine like vertical axis wind turbine, horizontal axis wind turbine, multi-axis wind turbine, etc. A system which lies on the efficiency frontier can be used as a benchmark for other resource/system to emulate by strengthening of their respective criteria.

\section{Conclusions}

An integrated fuzzy analytical hierarchy process and data envelopment approach is used to analyze the relative efficiency of various solar stills based on various input and output criteria. Relative weights of criteria are found using fuzzy AHP approach and the overall efficiency score for the 20 solar stills is determined using the data envelopment analysis. Though many solar stills are technically strong (high productivity) yet they are not economically strong (high fabrication, operation and maintenance cost) and hence do not find a place among the top solar stills. When the productivity is considered as the only criteria, then hybrid solar still, solar still sun tracking and solar still with solar pond is found to be at the top (Dsilva Winfred Rufuss et al., 2016; Kabeel and El-Agouz, 2011; Yadav and Sudhakar, 2015), but when the other parameters such as fabrication cost, economic impact, etc are considered then pyramid type solar still, still with PVT, still with NPCM $\left(\mathrm{CuO}, \mathrm{TiO}_{2}\right)$ and PCM goes to the top five position with 100, 100, 88, 88 and $77 \%$ relative efficiency respectively. It is inferred that, solar still with copper oxide requires a reduction in the skilled labour requirement or an improvement in its commercial potential and economic impact to reach the top position. Similarly, overall efficiency of other solar stills can be increased by concentrating on the pinpointed areas.

\section{Acknowledgements}

The authors gratefully acknowledge DST and British Council for providing financial support under UKIERI project funding scheme (DST/INT/UK/P-86/2014, UKIERI-DST-2014-15-03). Also, one of the authors Mr. Dsilva Winfred Rufuss gratefully acknowledge the award of Senior Research Fellow (SRF) under the Maulana Azad National Fellowship (MANF) program by the Ministry of Minority Affairs, University Grants Commission (UGC) New Delhi, Proceeding No. MANF-2015-17-TAM-48968. 


\section{References}

Abdallah, S., Badran, O., Abu-Khader, M.M., 2008. Performance evaluation of a modified design of a single slope solar still. Desalination 219, 222-230. doi:10.1016/j.desal.2007.05.015

Abdallah, S., Badran, O.O., 2008. Sun tracking system for productivity enhancement of solar still. Desalination 220, 669-676. doi:10.1016/j.desal.2007.02.047

Abdel-Rehim, Z.S., Lasheen, A., 2007. Experimental and theoretical study of a solar desalination system located in Cairo, Egypt. Desalination 217, 52-64. doi:10.1016/j.desal.2007.01.012

Ahsan, A., Imteaz, M., Rahman, A., Yusuf, B., Fukuhara, T., 2012. Design, fabrication and performance analysis of an improved solar still. Desalination 292, 105-112. doi:10.1016/j.desal.2012.02.013

Ali Samee, M., Mirza, U.K., Majeed, T., Ahmad, N., 2007. Design and performance of a simple single basin solar still. Renew. Sustain. Energy Rev. doi:10.1016/j.rser.2005.03.003

AlMarzooqi, F.A., Al Ghaferi, A.A., Saadat, I., Hilal, N., 2014. Application of Capacitive Deionisation in water desalination: A review. Desalination. doi:10.1016/j.desal.2014.02.031

Altaee, A., Hilal, N., 2015. High recovery rate NF-FO-RO hybrid system for inland brackish water treatment. Desalination 363, 19-25. doi:10.1016/j.desal.2014.12.017

Arunkumar, T., Jayaprakash, R., Ahsan, A., Denkenberger, D., Okundamiya, M.S., 2013. Effect of water and air flow on concentric tubular solar water desalting system. Appl. Energy 103, 109-115. doi:10.1016/j.apenergy.2012.09.014

Arunkumar, T., Jayaprakash, R., Denkenberger, D., Ahsan, A., Okundamiya, M.S., kumar, S., Tanaka, H., Aybar, H.Ş., 2012. An experimental study on a hemispherical solar still. Desalination 286, 342-348. doi:10.1016/j.desal.2011.11.047

Badran, A.A., Al-Hallaq, A.A., Eyal Salman, I.A., Odat, M.Z., 2005. A solar still augmented with a flat-plate collector. Desalination 172, 227-234. doi:10.1016/j.desal.2004.06.203

Badran, O.O., Al-Tahaineh, H.A., 2005. The effect of coupling a flat-plate collector on the solar still productivity. Desalination 183, 137-142. doi:10.1016/j.desal.2005.02.046

Baig, H., Antar, M.A., Zubair, S.M., 2011. Performance evaluation of a once-through multi-stage flash distillation system: Impact of brine heater fouling. Energy Convers. Manag. 52, 14141425. doi:10.1016/j.enconman.2010.10.004

Charnes, A., Cooper, W.W., Rhodes, E., 1978. Measuring the efficiency of decision making units. Eur. J. Oper. Res. 2, 429-444. doi:10.1016/0377-2217(78)90138-8

Choi, S.H., 2016. On the brine re-utilization of a multi-stage flashing (MSF) desalination plant. Desalination 398, 64-76. doi:10.1016/j.desal.2016.07.020

Criswell, D.R., Thompson, R.G., 1996. Data envelopment analysis of space and terrestriallybased large scale commercial power systems for earth: A prototype analysis of their relative economic advantages. Sol. Energy. doi:10.1016/0038-092X(95)00113-6

Davies, P.A., Harris, I., Knowles, P.R., 2006. Cooling of greenhouses using seawater: A solar driven liquid-desiccant cycle for greenhouse cooling in hot climates, in: Acta Horticulturae. pp. 139-146. 
Davies, P.A., Knowles, P.R., 2006. Seawater bitterns as a source of liquid desiccant for use in solar-cooled greenhouses. Desalination 196, 266-279. doi:10.1016/j.desal.2006.03.010

Davies, P.A., Paton, C., 2005. The Seawater Greenhouse in the United Arab Emirates: thermal modelling and evaluation of design options. Desalination 173, 103-111. doi:10.1016/j.desa1.2004.06.211

Davies, P., Turner, K., Paton, C., 2004. Potential of the Seawater Greenhouse in Middle Eastern Climates. Eng. Conf. 523-540.

Delgado-Torres, A.M., García-Rodríguez, L., 2010. Preliminary design of seawater and brackish water reverse osmosis desalination systems driven by low-temperature solar organic Rankine cycles (ORC). Energy Convers. Manag. 51, 2913-2920. doi:10.1016/j.enconman.2010.06.032

Dey, P.K., 2004. Analytic hierarchy process helps evaluate project in Indian oil pipelines industry. Int. J. Oper. Prod. Manag. 24, 588-604. doi:10.1108/01443570410538122

Dsilva Winfred Rufuss, D., Iniyan, S., Suganthi, L., Davies, P.A., 2017. Low mass fraction impregnation with graphene oxide (GO) enhances thermo-physical properties of paraffin for heat storage applications. Thermochim. Acta 655, 226-233. doi:10.1016/j.tca.2017.07.005

Dsilva Winfred Rufuss, D., Iniyan, S., Suganthi, L., Davies, P.A., 2016. Solar stills: A comprehensive review of designs, performance and material advances. Renew. Sustain. Energy Rev. 63, 464-496. doi:10.1016/j.rser.2016.05.068

El-Bahi, A., Inan, D., 1999. Analysis of a parallel double glass solar still with separate condenser. Renew. Energy 17, 509-521. doi:10.1016/S0960-1481(98)00768-X

El-Bialy, E., Shalaby, S.M., Kabeel, A.E., Fathy, A.M., 2016. Cost analysis for several solar desalination systems. Desalination 384, 12-30. doi:10.1016/j.desal.2016.01.028

El-Sebaii, A.A., Ramadan, M.R.I., Aboul-Enein, S., Salem, N., 2008. Thermal performance of a single-basin solar still integrated with a shallow solar pond. Energy Convers. Manag. 49, 2839-2848. doi:10.1016/j.enconman.2008.03.002

Elzahaby, A.M., Kabeel, A.E., Bassuoni, M.M., Elbar, A.R.A., 2016. Direct contact membrane water distillation assisted with solar energy. Energy Convers. Manag. 110, 397-406. doi:10.1016/j.enconman.2015.12.046

Fath, H.E.S., El-Samanoudy, M., Fahmy, K., Hassabou, A., 2003. Thermal-economic analysis and comparison between pyramid-shaped and single-slope solar still configurations. Desalination 159, 69-79. doi:10.1016/S0011-9164(03)90046-4

Gambier, A., Badreddin, E., 2003. Application of hybrid modeling and control techniques to desalination plants. Desalination 152, 175-184. doi:10.1016/S0011-9164(02)01060-3

Gaur, M.K., Tiwari, G.N., 2010. Optimization of number of collectors for integrated PV/T hybrid active solar still. Appl. Energy 87, 1763-1772. doi:10.1016/j.apenergy.2009.10.019

Hajeeh, M., 2010. Journal of industrial engineering international., Journal of Industrial Engineering, International. Islamic Azad University.

Hajeeh, M., Al-Othman, A., 2005. Application of the analytical hierarchy process in the selection of desalination plants. Desalination 174, 97-108. doi:10.1016/j.desal.2004.09.005 
Hilal, N., Kochkodan, V., Al Abdulgader, H., Johnson, D., 2015a. A combined ion exchangenanofiltration process for water desalination: II. Membrane selection. Desalination 363, 5157. doi:10.1016/j.desal.2014.11.017

Hilal, N., Kochkodan, V., Al Abdulgader, H., Mandale, S., Al-Jlil, S.A., 2015b. A combined ion exchange-nanofiltration process for water desalination: I. sulphate-chloride ion-exchange in saline solutions. Desalination 363, 44-50. doi:10.1016/j.desal.2014.11.016

Ismail, A., 1998. Fuzzy model reference learning control of multi-stage flash desalination plants. Desalination 116, 157-164. doi:10.1016/S0011-9164(98)00192-1

Ismail, B.I., 2009. Design and performance of a transportable hemispherical solar still. Renew. Energy 34, 145-150. doi:10.1016/j.renene.2008.03.013

Jovanović, B., Filipović, J., Bakić, V., 2015. Prioritization of manufacturing sectors in Serbia for energy management improvement - AHP method. Energy Convers. Manag. 98, 225-235. doi:10.1016/j.enconman.2015.03.107

Kabeel, A.E., El-Agouz, S.A., 2011. Review of researches and developments on solar stills. Desalination. doi:10.1016/j.desal.2011.03.042

Kabeel, A.E., Hamed, A.M., El-Agouz, S.A., 2010. Cost analysis of different solar still configurations. Energy 35, 2901-2908. doi:10.1016/j.energy.2010.03.021

Kamaraj, M., Sundar, J.V., Subramanian, V., 2016. Dioxin sensing properties of graphene and hexagonal boron nitride based van der Waals solids: a first-principles study. RSC Adv. 6. doi:10.1039/c6ra18976h

Kaushal, A., Varun, 2010. Solar stills: A review. Renew. Sustain. Energy Rev. doi:10.1016/j.rser.2009.05.011

Khanzada, N.K., Khan, S.J., Davies, P.A., 2017. Performance evaluation of reverse osmosis (RO) pre-treatment technologies for in-land brackish water treatment. Desalination 406, 44 50. doi:10.1016/j.desal.2016.06.030

Kumar, S., Tiwari, G.N., 2009. Life cycle cost analysis of single slope hybrid (PV/T) active solar still. Appl. Energy 86, 1995-2004. doi:10.1016/j.apenergy.2009.03.005

Lee, S.K., Mogi, G., Hui, K.S., 2013. A fuzzy analytic hierarchy process (AHP)/data envelopment analysis (DEA) hybrid model for efficiently allocating energy R\&D resources: In the case of energy technologies against high oil prices. Renew. Sustain. Energy Rev. 21, 347-355. doi:10.1016/j.rser.2012.12.067

Lee, S.K., Mogi, G., Li, Z., Hui, K.S., Lee, S.K., Hui, K.N., Park, S.Y., Ha, Y.J., Kim, J.W., 2011. Measuring the relative efficiency of hydrogen energy technologies for implementing the hydrogen economy: An integrated fuzzy AHP/DEA approach. Int. J. Hydrogen Energy 36, 12655-12663. doi:10.1016/j.ijhydene.2011.06.135

Mamlook, R., Al-Rawajfeh, A.E., 2008. Fuzzy set implementation for controlling and evaluation of factors affecting multiple-effect distillers. Desalination 222, 541-547. doi:10.1016/j.desal.2007.01.131

Mamlook, R., Badran, O., 2007. Fuzzy sets implementation for the evaluation of factors affecting solar still production. Desalination 203, 394-402. doi:10.1016/j.desal.2006.02.024

Mojallizadeh, M.R., Badamchizadeh, M.A., 2017. Second-order fuzzy sliding-mode control of 
photovoltaic power generation systems. Sol. Energy 149, 332-340.

doi:10.1016/j.solener.2017.04.014

Mokheimer, E.M.A., Sahin, A.Z., Al-Sharafi, A., Ali, A.I., 2013. Modeling and optimization of hybrid wind-solar-powered reverse osmosis water desalination system in Saudi Arabia. Energy Convers. Manag. 75, 86-97. doi:10.1016/j.enconman.2013.06.002

Mudgal, A., Davies, P.A., 2016. A cost-effective steam-driven RO plant for brackish groundwater. Desalination 385, 167-177. doi:10.1016/j.desal.2016.02.022

Muftah, A.F., Alghoul, M.A., Fudholi, A., Abdul-Majeed, M.M., Sopian, K., 2014. Factors affecting basin type solar still productivity: A detailed review. Renew. Sustain. Energy Rev. doi:10.1016/j.rser.2013.12.052

Murugavel, K.K., Sivakumar, S., Ahamed, J.R., Chockalingam, K.K.S.K., Srithar, K., 2010. Single basin double slope solar still with minimum basin depth and energy storing materials. Appl. Energy 87, 514-523. doi:10.1016/j.apenergy.2009.07.023

Nakoa, K., Rahaoui, K., Date, A., Akbarzadeh, A., 2015. An experimental review on coupling of solar pond with membrane distillation. Sol. Energy 119, 319-331. doi:10.1016/j.solener.2015.06.010

Nayi, K.H., Modi, K. V., 2018. Pyramid solar still: A comprehensive review. Renew. Sustain. Energy Rev. doi:10.1016/j.rser.2017.07.004

Nixon, J.D., Dey, P.K., Davies, P.A., 2010. Which is the best solar thermal collection technology for electricity generation in north-west India? Evaluation of options using the analytical hierarchy process. Energy 35, 5230-5240. doi:10.1016/j.energy.2010.07.042

Orfi, J., Loussif, N., Davies, P.A., 2016. Heat and mass transfer in membrane distillation used for desalination with slip flow. Desalination 381, 135-142. doi:10.1016/j.desal.2015.12.009

Qasim, M., Darwish, N.A., Sarp, S., Hilal, N., 2015. Water desalination by forward (direct) osmosis phenomenon: A comprehensive review. Desalination 374, 47-69. doi:10.1016/j.desal.2015.07.016

Rahbar, N., Esfahani, J.A., Asadi, A., 2016. An experimental investigation on productivity and performance of a new improved design portable asymmetrical solar still utilizing thermoelectric modules. Energy Convers. Manag. 118, 55-62. doi:10.1016/j.enconman.2016.03.052

Rao Nulakani, N.V., Kamaraj, M., Subramanian, V., 2015. Coro-graphene and circumcorographyne: novel two-dimensional materials with exciting electronic properties. RSC Adv. 5, 78910-78916. doi:10.1039/C5RA14477A

Rufuss, D.D.W., Iniyan, S., Suganthi, L., Davies, P.A., Akinaga, T., 2015. Analysis of solar still with nanoparticle incorporated phase change material for solar desalination application 812.

Sakthivel, M., Shanmugasundaram, S., Alwarsamy, T., 2010. An experimental study on a regenerative solar still with energy storage medium - Jute cloth. Desalination 264, 24-31. doi:10.1016/j.desal.2010.06.074

Sathyamurthy, R., El-Agouz, S.A., Nagarajan, P.K., Subramani, J., Arunkumar, T., Mageshbabu, D., Madhu, B., Bharathwaaj, R., Prakash, N., 2017. A Review of integrating solar collectors to solar still. Renew. Sustain. Energy Rev. doi:10.1016/j.rser.2016.11.223 
Shalaby, S.M., El-Bialy, E., El-Sebaii, A.A., 2016. An experimental investigation of a vcorrugated absorber single-basin solar still using PCM. Desalination 398, 247-255. doi:10.1016/j.desal.2016.07.042

Sharshir, S.W., Peng, G., Yang, N., Eltawil, M.A., Ali, M.K.A., Kabeel, A.E., 2016. A hybrid desalination system using humidification-dehumidification and solar stills integrated with evacuated solar water heater. Energy Convers. Manag. 124, 287-296. doi:10.1016/j.enconman.2016.07.028

Tanha Aminloei, R., Ghaderi, S.F., 2010. Generation planning in Iranian power plants with fuzzy hierarchical production planning. Energy Convers. Manag. 51, 1230-1241. doi:10.1016/j.enconman.2009.12.034

Taylan, O., Kaya, D., Demirbas, A., 2016. An integrated multi attribute decision model for energy efficiency processes in petrochemical industry applying fuzzy set theory. Energy Convers. Manag. 117, 501-512. doi:10.1016/j.enconman.2016.03.048

Tiwari, G.N., Sahota, L., 2017. Review on the energy and economic efficiencies of passive and active solar distillation systems. Desalination 401, 151-179. doi:10.1016/j.desal.2016.08.023

Tsakiris, G., Spiliotis, M., Paritsis, S., Alexakis, D., 2009. Assessing the water potential of karstic saline springs by applying a fuzzy approach: The case of Almyros (Heraklion, Crete). Desalination 237, 54-64. doi:10.1016/j.desal.2007.12.022

Velmurugan, V., Deenadayalan, C.K., Vinod, H., Srithar, K., 2008a. Desalination of effluent using fin type solar still. Energy 33, 1719-1727. doi:10.1016/j.energy.2008.07.001

Velmurugan, V., Gopalakrishnan, M., Raghu, R., Srithar, K., 2008b. Single basin solar still with fin for enhancing productivity. Energy Convers. Manag. 49, 2602-2608. doi:10.1016/j.enconman.2008.05.010

Velmurugan, V., Naveen Kumar, K.J., Noorul Haq, T., Srithar, K., 2009. Performance analysis in stepped solar still for effluent desalination. Energy 34, 1179-1186. doi:10.1016/j.energy.2009.04.029

Velmurugan, V., Srithar, K., 2011. Performance analysis of solar stills based on various factors affecting the productivity - A review. Renew. Sustain. Energy Rev. doi:10.1016/j.rser.2010.10.012

Velmurugan, V., Srithar, K., 2007. Solar stills integrated with a mini solar pond - analytical simulation and experimental validation. Desalination 216, 232-241. doi:10.1016/j.desal.2006.12.012

Voropoulos, K., Mathioulakis, E., Belessiotis, V., 2001. Experimental investigation of a solar still coupled with solar collectors. Desalination 138, 103-110. doi:10.1016/S00119164(01)00251-X

Wang, C.C., 2011. On the heat transfer correlation for membrane distillation. Energy Convers. Manag. 52, 1968-1973. doi:10.1016/j.enconman.2010.11.014

Yadav, S., Sudhakar, K., 2015. Different domestic designs of solar stills: A review. Renew. Sustain. Energy Rev. 47, 718-731. doi:10.1016/j.rser.2015.03.064

Yetilmezsoy, K., Abdul-Wahab, S.A., 2014. A composite desirability function-based modeling approach in predicting mass condensate flux of condenser in seawater greenhouse. 
Yu, Z., Dexter, A., 2010. Hierarchical fuzzy control of low-energy building systems. Sol. Energy 84, 538-548. doi:10.1016/j.solener.2009.03.014

Zhang, Y., Peng, Y., Ji, S., Li, Z., Chen, P., 2015. Review of thermal efficiency and heat recycling in membrane distillation processes. Desalination. doi:10.1016/j.desal.2015.04.013

Zilouchian, A., Jafar, M., 2001. Automation and process control of reverse osmosis plants using soft computing methodologies. Desalination 135, 51-59. doi:10.1016/S00119164(01)00138-2

\section{List of Tables}

Table 1 Five point scale for various input and output criteria

Table 2 Triangular fuzzy (TFN) scale and its inverse TFN scale

Table 3 Demographic details of the experts

Table 4 CR value for the input and output criteria

Table 5 Pairwise comparison

Table 6 Comparing the values of fuzzy synthetic extent

Table 7 Fuzzy AHP weights for Input criteria

Table 8 Upper and lower bounds of weights input criteria

Table 9 Fuzzy AHP weights for output criteria

Table 10 Upper and lower bounds of weights output criteria

Table 11 Input/output criteria for 20 solar stills

Table 12 Weight distribution of AR-CCR (with weight restriction)

Table 13 Efficiency and rank of solar stills 


\section{List of Figures}

Fig. 1. Detailed tabulation showing classification of desalination processes (Nayi and Modi, 2018)

Fig. 2. Various types of solar stills (Tiwari and Sahota, 2017)

Fig. 3. Various climate, design and operational parameters influencing the productivity of solar still (Muftah et al., 2014)

Fig. 4. Setup of simple single slope solar still (Ali Samee et al., 2007)

Fig. 5. Schematic of solar still with sun tracking system (Abdallah et al., 2008)

Fig. 6. Solar still integrated with photo-voltaic thermal (PVT) system (Kumar and Tiwari, 2009)

Fig. 7. Solar still integrated with flat-plate collector (Badran and Al-Tahaineh, 2005)

Fig. 8. Schematic of solar still integrated with concentrators (Abdel-Rehim and Lasheen, 2007)

Fig. 9. Schematic setup of solar still integrated with fin (Velmurugan et al., 2008a)

Fig. 10. Pictorial representation of hemispherical solar still (Ismail, 2009)

Fig. 11. Schematic configuration of pyramid type solar still (Fath et al., 2003)

Fig. 12. Schematic of solar still with sponge (Velmurugan et al., 2008b)

Fig. 13. Solar still with phase change material (PCM) (Shalaby et al., 2016)

Fig. 14. Overall methodology of integrated fuzzy AHP DEA

Fig. 15. Hierarchical structure of various input and output criteria used in DEA

Fig. 16. Input/output criteria for the twenty solar stills

Fig. 17. Efficiency decomposition of twenty solar stills 
Table 1

Five point scale for various input and output criteria

\begin{tabular}{|c|c|c|c|}
\hline a. & Skilled labour requirement & & Land area requirement \\
\hline Scale & Definition & Scale & Definition \\
\hline 1 & More than 5 person required & 1 & $\begin{array}{l}\text { More than three active components are coupled with } \\
\text { still }\end{array}$ \\
\hline 2 & At least 4 person required & 2 & Two components are coupled with still \\
\hline 3 & At least 3 person required & 3 & One active component is coupled with still \\
\hline 4 & At least 2 person required & 4 & Complexity in design and size \\
\hline 5 & One person is enough & 5 & No active component is coupled with still \\
\hline c. & Economic impact & d. & Commercial potential \\
\hline Scale & Definition & Scale & Definition \\
\hline 1 & The annual maintenance cost of the system above $80 \$ / \mathrm{m}^{2}$ & 1 & Research and development stage \\
\hline 2 & $\begin{array}{l}\text { The annual maintenance cost of the system between } 60-80 \\
\$ / \mathrm{m}^{2}\end{array}$ & 2 & Technology transfer stage \\
\hline 3 & $\begin{array}{l}\text { The annual maintenance cost of the system between } 40-60 \\
\$ / \mathrm{m}^{2}\end{array}$ & 3 & Patent acquirement stage \\
\hline 4 & $\begin{array}{l}\text { The annual maintenance cost of the system between } 20-40 \\
\$ / \mathrm{m}^{2}\end{array}$ & 4 & In the phase of dissemination \\
\hline 5 & $\begin{array}{l}\text { The annual maintenance cost of the system between than } 0 \text { - } \\
20 \$ / \mathrm{m}^{2}\end{array}$ & 5 & In the phase of commercialization \\
\hline e. & Productivity & f. & Technical complexity \\
\hline Scale & Definition & Scale & Definition \\
\hline 1 & Average annual productivity ranges between $0-250 \mathrm{lit} / \mathrm{m}^{2}$ & 1 & Solar still coupled with two or more component \\
\hline 2 & Average annual productivity ranges between $250-500 \mathrm{lit} / \mathrm{m}^{2}$ & 2 & Solar still coupled with any one component \\
\hline 3 & Average annual productivity ranges between $500-750 \mathrm{lit} / \mathrm{m}^{2}$ & 3 & Modifying the design of conventional still setup \\
\hline 4 & $\begin{array}{l}\text { Average annual productivity ranges between } 750-1000 \\
\mathrm{lit} / \mathrm{m}^{2}\end{array}$ & 4 & $\begin{array}{l}\text { Small modification in the existing conventional still } \\
\text { setup }\end{array}$ \\
\hline 5 & Average annual productivity ranges above $1000 \mathrm{lit} / \mathrm{m}^{2}$ & 5 & Conventional setup \\
\hline
\end{tabular}


Table 2

Triangular fuzzy (TFN) scale and its inverse TFN scale

\begin{tabular}{lll}
\hline Scale of importance & Triangular fuzzy scale & $\begin{array}{l}\text { Triangular } \\
\text { fuzzy inverse } \\
\text { scale }\end{array}$ \\
\hline Equally important & $(1,1,1)$ & $(1,1,1)$ \\
Moderately important & $(1 / 2,1,3 / 2)$ & $(2 / 3,1,2)$ \\
Moderately more important & $(1,3 / 2,2)$ & $(1 / 2,2 / 3,1)$ \\
Strongly important & $(3 / 2,2,5 / 2)$ & $(2 / 5,1 / 2,2 / 3)$ \\
Very strongly important & $(2,5 / 2,3)$ & $(1 / 3,2 / 5,1 / 2)$ \\
Absolutely extremely important & $(5 / 2,3,7 / 2)$ & $(2 / 7,1 / 3,2 / 5)$ \\
\hline
\end{tabular}


able 3 Demographic details of the experts

Table 3

Demographic details of the experts

\begin{tabular}{lllll}
\hline Type of experts & \multicolumn{3}{c}{ Years of experience } & \multirow{2}{*}{ Specialization } \\
\cline { 2 - 3 } & $\begin{array}{l}10 \\
\text { years }\end{array}$ & $\begin{array}{c}15 \text { years } \\
\text { above }\end{array}$ & \\
\hline Academicians & 0 & 2 & Renewable energy \\
Industrialists & 0 & 3 & Desalination \\
Researchers & 2 & 3 & Solar still \\
\hline
\end{tabular}


Table 4

$\mathrm{CR}$ value for the input and output criteria

\begin{tabular}{lll}
\hline Experts & \multicolumn{2}{c}{ CR value for } \\
\cline { 2 - 3 } & Input criteria & Output criteria \\
\hline Expert 1 & 0.056352 & 0.081938 \\
Expert 2 & 0 & 0.07702 \\
Expert 3 & 0.017789 & 0 \\
Expert 4 & 0.05234 & 0.021225 \\
Expert 5 & 0.056352 & 0.031959 \\
Expert 6 & 0.056352 & 0.092605 \\
Expert 7 & 0.032986 & 0.083818 \\
Expert 8 & 0.009503 & 0.085752 \\
Expert 9 & 0.061082 & 0.088472 \\
Expert 10 & 0.020183 & 0.0923 \\
\hline
\end{tabular}




\section{Table 5}

Pairwise comparison for Expert-1

\begin{tabular}{llll}
\hline & SL & FC & LA \\
\hline SL & $(1,1,1)$ & $(3 / 2,2,5 / 2)$ & $(1 / 2,2 / 3,1)$ \\
FC & $(2 / 5,1 / 2,2 / 3)$ & $(1,1,1)$ & $(2 / 5,1 / 2,2 / 3)$ \\
LA & $(1,3 / 2,2)$ & $(3 / 2,2,5 / 2)$ & $(1,1,1)$ \\
\hline
\end{tabular}


able 6 Comparing the values of fuzzy synthetic extent

Table 6

Comparing the values of fuzzy synthetic extent

\begin{tabular}{ll}
\hline $\mathrm{V}\left(\mathrm{S}_{1} \geq \mathrm{S}_{\mathrm{j}}\right)$ & Value \\
\hline $\mathrm{V}\left(\mathrm{S}_{1} \geq \mathrm{S}_{2}\right)$ & 1 \\
$\mathrm{~V}\left(\mathrm{~S}_{1} \geq \mathrm{S}_{3}\right)$ & 0.759169 \\
\hline $\mathrm{V}\left(\mathrm{S}_{2} \geq \mathrm{S}_{\mathrm{j}}\right)$ & Value \\
\hline $\mathrm{V}\left(\mathrm{S}_{2} \geq \mathrm{S}_{1}\right)$ & 0.187702 \\
$\mathrm{~V}\left(\mathrm{~S}_{2} \geq \mathrm{S}_{3}\right)$ & 0 \\
\hline $\mathrm{V}\left(\mathrm{S}_{3} \geq \mathrm{S}_{\mathrm{j}}\right)$ & Value \\
\hline $\mathrm{V}\left(\mathrm{S}_{3} \geq \mathrm{S}_{1}\right)$ & 1 \\
$\mathrm{~V}\left(\mathrm{~S}_{3} \geq \mathrm{S}_{2}\right)$ & 1 \\
\hline
\end{tabular}


Table 7

Fuzzy AHP weights for Input criteria

\begin{tabular}{llll}
\hline Experts & SL & FC & LA \\
\hline Expert 1 & 0.43155 & & 0.56845 \\
Expert 2 & 0.932849 & & 0.067151 \\
Expert 3 & 0.391644 & 0.45041 & 0.157945 \\
Expert 4 & 0.343264 & 0.449537 & 0.207199 \\
Expert 5 & 0.43155 & 0.56845 & \\
Expert 6 & & 0.43155 & 0.56845 \\
Expert 7 & 1 & & \\
Expert 8 & & 0.529104 & 0.470896 \\
Expert 9 & & 0.568981 & 0.431019 \\
Expert 10 & 0.379857 & & 0.620143 \\
\hline
\end{tabular}


Table 8 Upper and lower bounds of weights input criteria

Table 8

Upper and lower bounds of weights input criteria

Input weight ratio Lower Upper bound

bound

$\mathrm{u} 1 / \mathrm{u} 2=\mathrm{SL} / \mathrm{FC} \quad 0.759169 \quad 0.869528$

$\mathrm{u} 1 / \mathrm{u} 3=\mathrm{SL} / \mathrm{LA} \quad 0.612532 \quad 13.89189$

$\mathrm{u} 2 / \mathrm{u} 3=\mathrm{FC} / \mathrm{LA} \quad 0.759169 \quad 2.81687$ 
Table 9

Fuzzy AHP weights for output criteria

\begin{tabular}{|c|c|c|c|c|c|}
\hline Experts & EI & $\mathrm{CP}$ & $P$ & $\mathrm{TC}$ & Total \\
\hline Expert 1 & 0.175001 & & & 0.824999 & 1 \\
\hline Expert 2 & & 0.237335 & & 0.762665 & 1 \\
\hline Expert 3 & 0.30111 & 0.09667 & 0.30111 & 0.30111 & 1 \\
\hline Expert 4 & 0.247096 & 0.421012 & 0.246513 & 0.085379 & 1 \\
\hline Expert 5 & 0.104572 & 0.187767 & 0.20532 & 0.502341 & 1 \\
\hline Expert 6 & 0.140981 & 0.501199 & 0.35782 & & 1 \\
\hline Expert 7 & 0.424853 & & 0.074449 & 0.500698 & 1 \\
\hline Expert 8 & 0.346887 & 0.336262 & & 0.316851 & 1 \\
\hline Expert 9 & 0.477976 & 0.269775 & 0.252249 & & 1 \\
\hline Expert 10 & 0.044319 & 0.399463 & & 0.556218 & 1 \\
\hline
\end{tabular}


able 10 Upper and lower bounds of weights output criteria

Table 10

Upper and lower bounds of weights output criteria

\begin{tabular}{lll}
\hline Output weight ratio & Lower bound & Upper bound \\
\hline $\mathrm{u} 1 / \mathrm{u} 2=\mathrm{EI} / \mathrm{CP}$ & 0.110947 & 3.11482 \\
$\mathrm{u} 1 / \mathrm{u} 3=\mathrm{EI} / \mathrm{P}$ & 0.394 & 5.706604 \\
$\mathrm{u} 1 / \mathrm{u} 4=\mathrm{EI} / \mathrm{TS}$ & 0.07968 & 2.89411 \\
$\mathrm{u} 2 / \mathrm{u} 3=\mathrm{CP} / \mathrm{P}$ & 0.321046 & 1.707865 \\
$\mathrm{u} 2 / \mathrm{u} 4=\mathrm{CP} / \mathrm{TS}$ & 0.311192 & 4.931093 \\
$\mathrm{u} 3 / \mathrm{u} 4=\mathrm{P} / \mathrm{TS}$ & 0.148691 & 2.887284 \\
\hline
\end{tabular}


Table 11

Input/output criteria for 20 solar stills

\begin{tabular}{|c|c|c|c|c|c|c|c|c|}
\hline Type of Solar still & References & SL & $\mathrm{FC}$ & LA & EI & $\mathrm{CP}$ & $\mathrm{P}$ & TC \\
\hline Solar still with wick and fin & (Velmurugan et al., 2008b) & 3 & 250 & 4 & 3 & 1 & 3 & 1 \\
\hline Transportable hemispherical solar still & (Ismail, 2009) & 3 & 1916 & 4 & 1 & 1 & 5 & 3 \\
\hline Stepped solar still with wick and sponge & (Velmurugan et al., 2009) & 3 & 360 & 4 & 2 & 1 & 5 & 1 \\
\hline Stepped solar still with sun tracking system & (Abdallah et al., 2008) & 1 & 729.16 & 3 & 1 & 1 & 5 & 2 \\
\hline weir type solar still & (Sadineni et al., 2008) & 3 & 288.95 & 4 & 3 & 1 & 5 & 3 \\
\hline solar still with sponge and pond & (Velmurugan and Srithar, 2007) & 3 & 350 & 3 & 2 & 1 & 4 & 1 \\
\hline soar still with shallow solar pond & (El-Sebaii et al., 2008) & 2 & 320 & 3 & 2 & 1 & 5 & 2 \\
\hline solar still with condenser & (El-Bahi and Inan, 1999) & 3 & 350 & 3 & 2 & 1 & 5 & 2 \\
\hline single slope solar still & (Ali Samee et al., 2007) & 5 & 345.45 & 5 & 4 & 1 & 5 & 5 \\
\hline single slope solar still with PVT & (Kumar and Tiwari, 2009) & 1 & 250 & 2 & 3 & 1 & 2 & 5 \\
\hline solar still with collector & (Badran and Al-Tahaineh, 2005) & 3 & 480 & 3 & 1 & 1 & 4 & 2 \\
\hline solar still with concentrator & (Abdel-Rehim and Lasheen, 2007) & 3 & 300 & 3 & 3 & 1 & 4 & 2 \\
\hline solar still with sun tracking & (Abdallah and Badran, 2008) & 3 & 300 & 3 & 3 & 1 & 1 & 2 \\
\hline Pyramid shape solar still & (Fath et al., 2003) & 2 & 173.61 & 4 & 4 & 1 & 5 & 3 \\
\hline Pyramid shape solar still with collector & (Badran et al., 2005) & 1 & 488.06 & 4 & 1 & 1 & 4 & 1 \\
\hline solar still with fin & (Velmurugan et al., 2008a) & 3 & 200 & 4 & 4 & 1 & 3 & 4 \\
\hline Solar still with PCM & (Rufuss et al., 2015) & 4 & 178.9 & 4 & 4 & 1 & 5 & 4 \\
\hline Solar still with Nano PCM (Titanium di oxide) & (Rufuss et al., 2015) & 3 & 179.34 & 4 & 4 & 1 & 5 & 4 \\
\hline Solar still with Nano PCM (Graphene oxide) & (Rufuss et al., 2015) & 3 & 618.9 & 4 & 1 & 1 & 5 & 4 \\
\hline Solar still with Nano PCM (Copper oxide) & (Rufuss et al., 2015) & 3 & 179.26 & 4 & 4 & 1 & 5 & 4 \\
\hline Average & & 2.75 & 412.88 & 3.6 & 2.6 & 1 & 4.25 & 2.75 \\
\hline
\end{tabular}


Table 12

Weight distribution of AR-CCR (with weight restriction)

\begin{tabular}{|c|c|c|c|c|c|c|c|}
\hline \multicolumn{8}{|c|}{ AR-CCR (with weight restriction) } \\
\hline & \multicolumn{3}{|c|}{ Input weights } & \multicolumn{4}{|c|}{ Output weights } \\
\hline Type of Solar still & SL & FC & LA & EI & $\mathrm{CP}$ & $\mathrm{P}$ & TC \\
\hline Solar still with wick and fin & 0.0076 & 0.0100 & 0.0035 & 0.0027 & 0.0046 & 0.0027 & 0.0009 \\
\hline Transportable hemispherical solar still & 0.0049 & 0.0056 & 0.0074 & 0.0019 & 0.0016 & 0.0049 & 0.0017 \\
\hline Stepped solar still with wick and sponge & 0.0063 & 0.0083 & 0.0043 & 0.0020 & 0.0017 & 0.0052 & 0.0018 \\
\hline Stepped solar still with sun tracking system & 0.0052 & 0.0060 & 0.0079 & 0.0021 & 0.0017 & 0.0053 & 0.0018 \\
\hline weir type solar still & 0.0052 & 0.0069 & 0.0035 & 0.0017 & 0.0014 & 0.0043 & 0.0015 \\
\hline solar still with sponge and pond & 0.0051 & 0.0068 & 0.0084 & 0.0013 & 0.0055 & 0.0032 & 0.0011 \\
\hline soar still with shallow solar pond & 0.0044 & 0.0058 & 0.0072 & 0.0019 & 0.0016 & 0.0049 & 0.0017 \\
\hline solar still with condenser & 0.0044 & 0.0058 & 0.0072 & 0.0019 & 0.0016 & 0.0049 & 0.0017 \\
\hline single slope solar still & 0.0033 & 0.0044 & 0.0054 & 0.0014 & 0.0012 & 0.0037 & 0.0013 \\
\hline single slope solar still with PVT & 0.0048 & 0.0064 & 0.0079 & 0.0003 & 0.0013 & 0.0008 & 0.0043 \\
\hline solar still with collector & 0.0052 & 0.0068 & 0.0084 & 0.0013 & 0.0056 & 0.0033 & 0.0011 \\
\hline solar still with concentrator & 0.0046 & 0.0061 & 0.0075 & 0.0020 & 0.0016 & 0.0051 & 0.0018 \\
\hline solar still with sun tracking & 0.0057 & 0.0075 & 0.0093 & 0.0030 & 0.0051 & 0.0030 & 0.0010 \\
\hline Pyramid shape solar still & 0.0056 & 0.0073 & 0.0026 & 0.0025 & 0.0023 & 0.0025 & 0.0009 \\
\hline Pyramid shape solar still with collector & 0.0087 & 0.0100 & 0.0035 & 0.0013 & 0.0058 & 0.0034 & 0.0012 \\
\hline solar still with fin & 0.0060 & 0.0079 & 0.0028 & 0.0035 & 0.0011 & 0.0025 & 0.0012 \\
\hline Solar still with PCM & 0.0047 & 0.0062 & 0.0032 & 0.0015 & 0.0012 & 0.0038 & 0.0013 \\
\hline Solar still with Nano PCM (Titanium di oxide) & 0.0047 & 0.0062 & 0.0032 & 0.0015 & 0.0012 & 0.0038 & 0.0013 \\
\hline Solar still with Nano PCM (Graphene oxide) & 0.0043 & 0.0053 & 0.0070 & 0.0018 & 0.0015 & 0.0046 & 0.0016 \\
\hline Solar still with Nano PCM (Copper oxide) & 0.0047 & 0.0062 & 0.0032 & 0.0015 & 0.0012 & 0.0038 & 0.0013 \\
\hline No. of Zeros in weights & 0 & 0 & 0 & 0 & 0 & 0 & 0 \\
\hline
\end{tabular}


Table 13

Efficiency and rank of solar stills

\begin{tabular}{|c|c|c|c|c|c|c|c|c|c|}
\hline \multirow[b]{2}{*}{ Type of Solar still } & \multicolumn{8}{|c|}{ Efficiency decomposition } & \multirow[b]{2}{*}{ Rank } \\
\hline & Efficiency & SL & $\mathrm{FC}$ & LA & EI & $\mathrm{CP}$ & $\mathrm{P}$ & $\mathrm{TC}$ & \\
\hline Solar still with wick and fin & 0.5504 & 0.8253 & 0.6034 & 0.3883 & 0.3129 & 0.4621 & 0.1910 & 0.0341 & 12 \\
\hline $\begin{array}{l}\text { Transportable hemispherical } \\
\text { solar still }\end{array}$ & 0.2533 & 0.5310 & 2.5976 & 0.8192 & 0.0748 & 0.1584 & 0.5804 & 0.1864 & 20 \\
\hline $\begin{array}{l}\text { Stepped solar still with wick and } \\
\text { sponge }\end{array}$ & 0.5277 & 0.6909 & 0.7273 & 0.4767 & 0.1573 & 0.1666 & 0.6107 & 0.0654 & 15 \\
\hline $\begin{array}{l}\text { Stepped solar still with sun } \\
\text { tracking system }\end{array}$ & 0.5269 & 0.1887 & 1.0540 & 0.6551 & 0.0797 & 0.1689 & 0.6189 & 0.1325 & 16 \\
\hline weir type solar still & 0.6905 & 0.5712 & 0.4827 & 0.3942 & 0.1951 & 0.1378 & 0.5049 & 0.1622 & 8 \\
\hline solar still with sponge and pond & 0.5468 & 0.5591 & 0.5723 & 0.6973 & 0.0985 & 0.5549 & 0.3058 & 0.0409 & 13 \\
\hline soar still with shallow solar pond & 0.7279 & 0.3214 & 0.4512 & 0.6012 & 0.1477 & 0.1564 & 0.5732 & 0.1227 & 7 \\
\hline solar still with condenser & 0.6342 & 0.4821 & 0.4935 & 0.6012 & 0.1477 & 0.1564 & 0.5732 & 0.1227 & 10 \\
\hline single slope solar still & 0.5809 & 0.6034 & 0.3657 & 0.7524 & 0.2218 & 0.1175 & 0.4304 & 0.2304 & 11 \\
\hline single slope solar still with PVT & 1.0000 & 0.1758 & 0.3856 & 0.4385 & 0.0399 & 0.1349 & 0.0372 & 0.7881 & 1 \\
\hline solar still with collector & 0.4858 & 0.5638 & 0.7914 & 0.7031 & 0.0496 & 0.5595 & 0.3083 & 0.0825 & 19 \\
\hline solar still with concentrator & 0.6368 & 0.5026 & 0.4410 & 0.6268 & 0.2309 & 0.1631 & 0.4781 & 0.1279 & 9 \\
\hline solar still with sun tracking & 0.5129 & 0.6240 & 0.5474 & 0.7781 & 0.3451 & 0.5096 & 0.0702 & 0.0752 & 17 \\
\hline Pyramid shape solar still & 1.0000 & 0.4053 & 0.3087 & 0.2860 & 0.3855 & 0.2260 & 0.2941 & 0.0944 & 2 \\
\hline $\begin{array}{l}\text { Pyramid shape solar still with } \\
\text { collector }\end{array}$ & 0.5304 & 0.3157 & 1.1804 & 0.3891 & 0.0518 & 0.5836 & 0.3216 & 0.0430 & 14 \\
\hline solar still with fin & 0.7437 & 0.6542 & 0.3826 & 0.3078 & 0.5344 & 0.1115 & 0.1795 & 0.1746 & 6 \\
\hline Solar still with PCM & 0.7693 & 0.6806 & 0.2671 & 0.3522 & 0.2325 & 0.1231 & 0.4512 & 0.1932 & 5 \\
\hline $\begin{array}{l}\text { Solar still with Nano-PCM } \\
\left(\text { paraffin }+\mathrm{TiO}_{2}\right)\end{array}$ & 0.8846 & 0.5105 & 0.2677 & 0.3522 & 0.2325 & 0.1231 & 0.4512 & 0.1932 & 4 \\
\hline $\begin{array}{l}\text { Solar still with Nano-PCM } \\
(\text { paraffin }+\mathrm{GO})\end{array}$ & 0.4870 & 0.4704 & 0.8010 & 0.7821 & 0.0704 & 0.1491 & 0.5465 & 0.2340 & 18 \\
\hline $\begin{array}{l}\text { Solar still with Nano-PCM } \\
\text { (paraffin }+\mathrm{CO})\end{array}$ & 0.8847 & 0.5105 & 0.2676 & 0.3522 & 0.2325 & 0.1231 & 0.4512 & 0.1932 & 3 \\
\hline
\end{tabular}




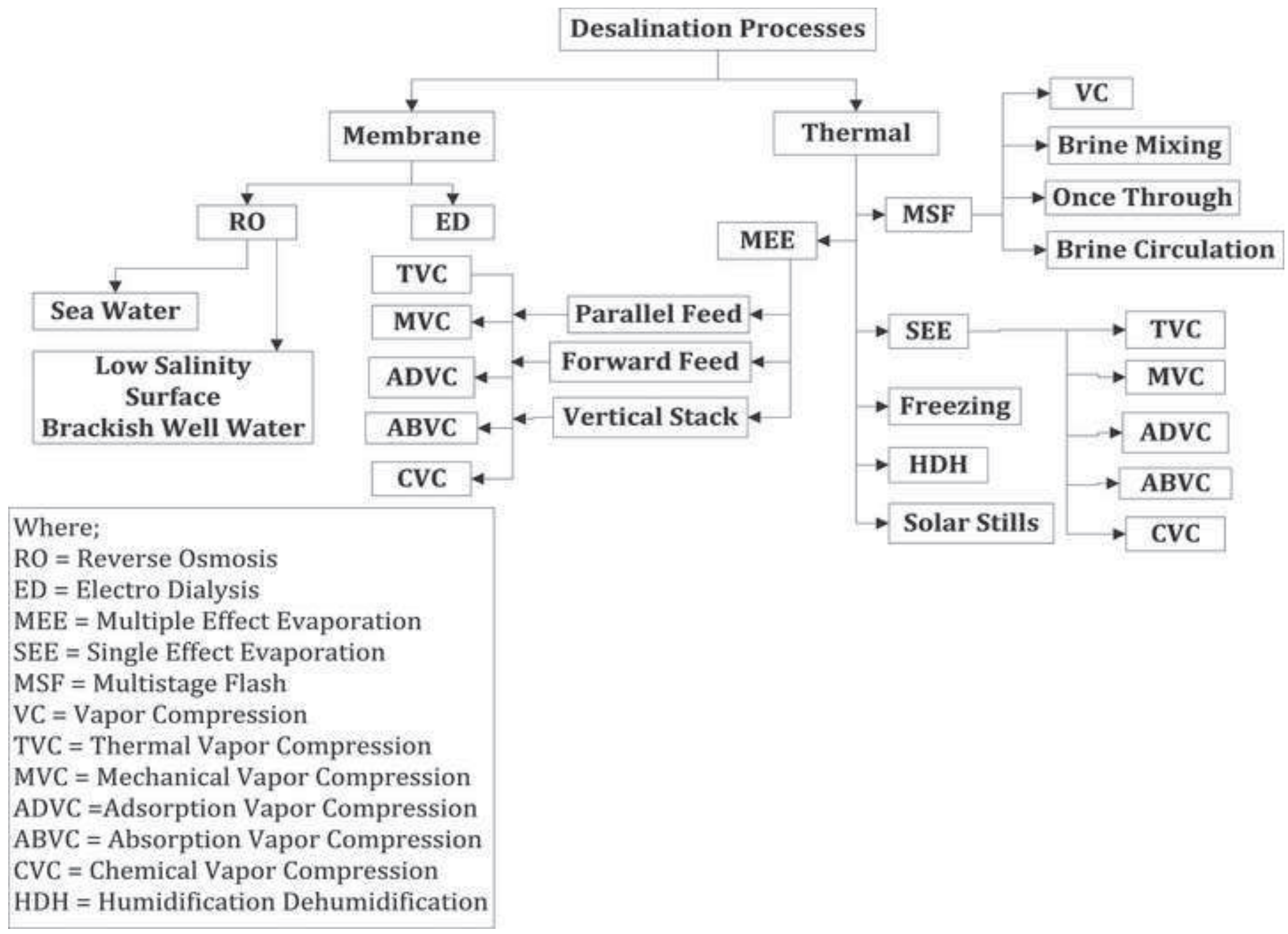



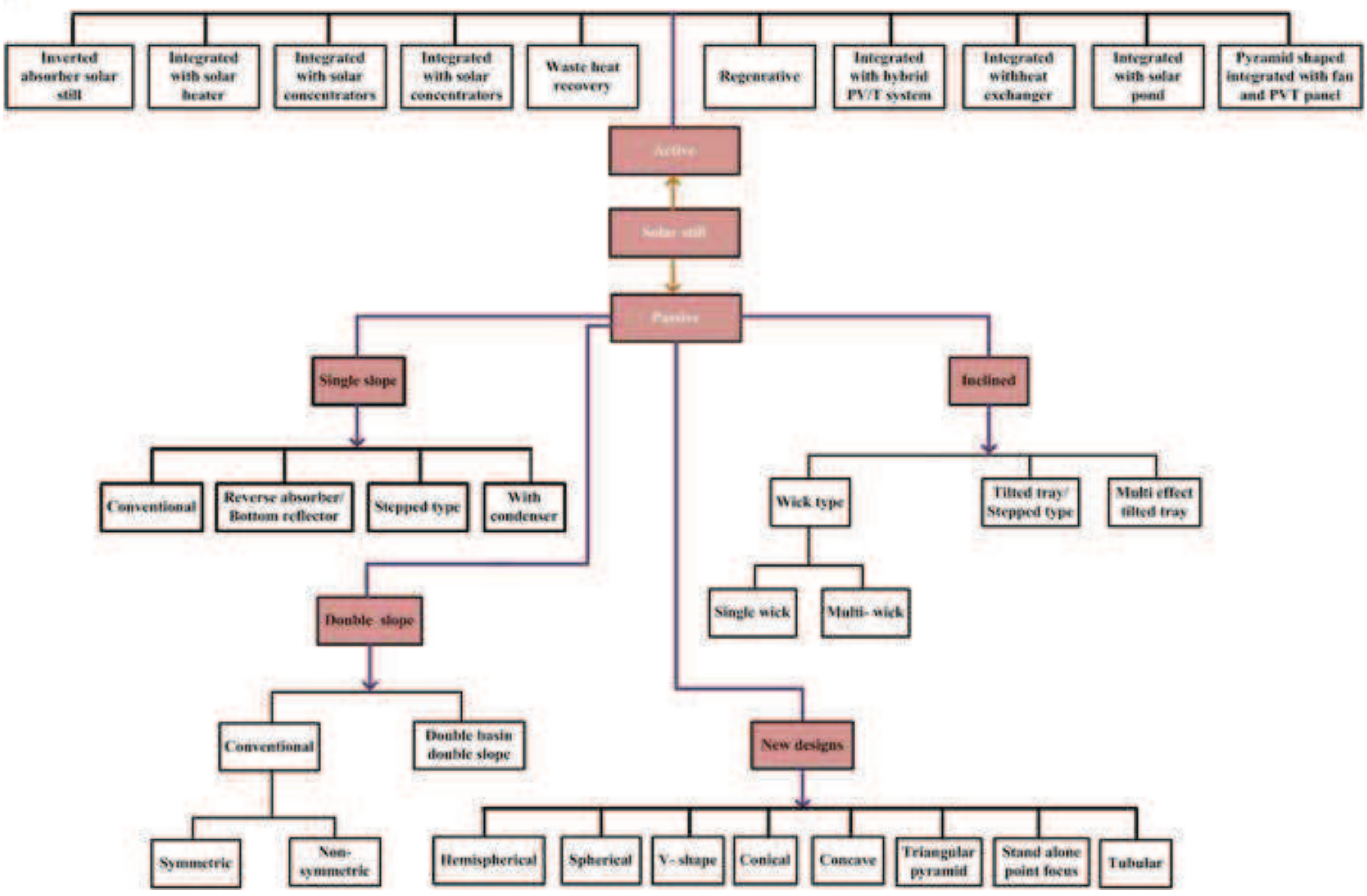
ig. 3. Various climate, design and operational parameters inf.. Click here to download high resolution image

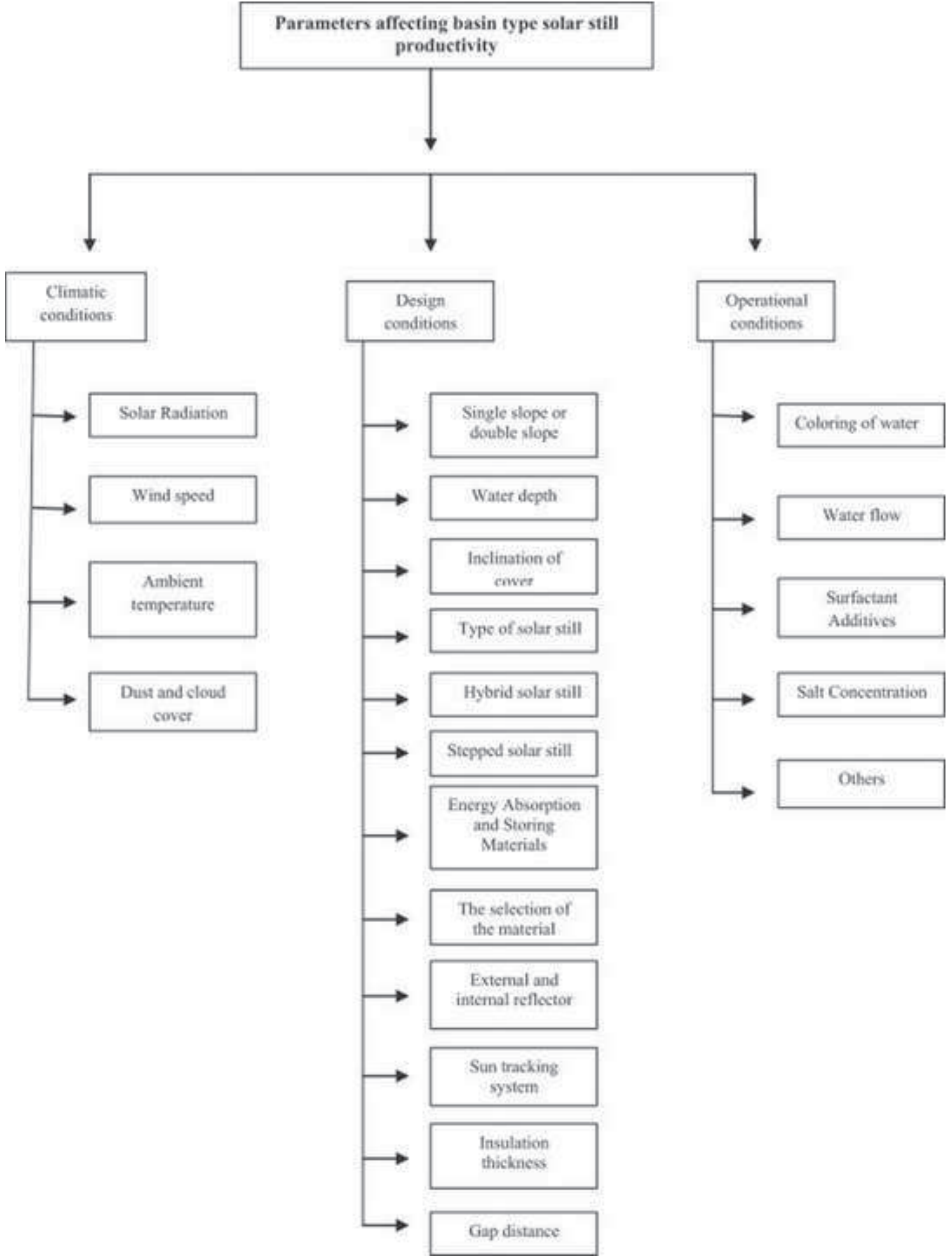




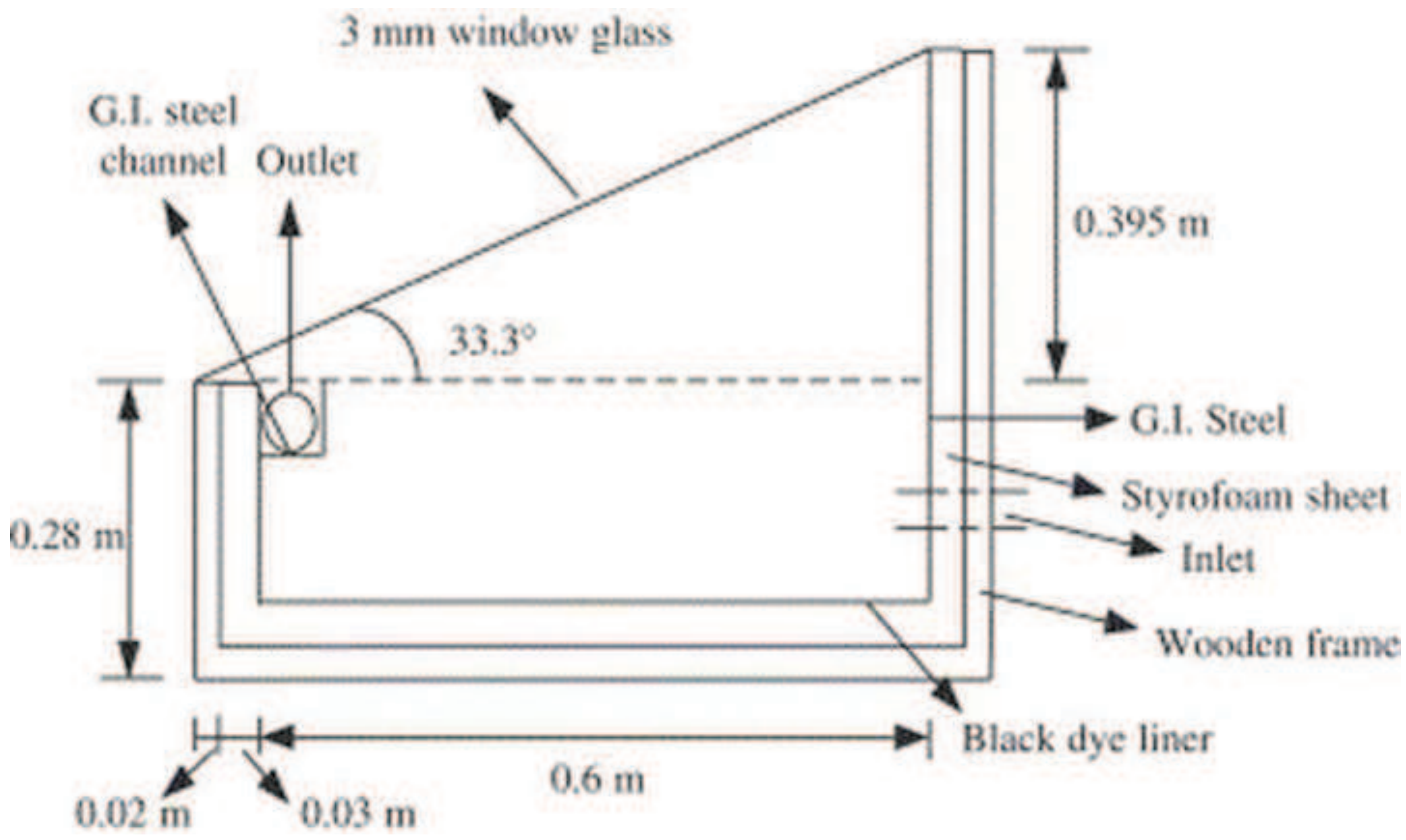



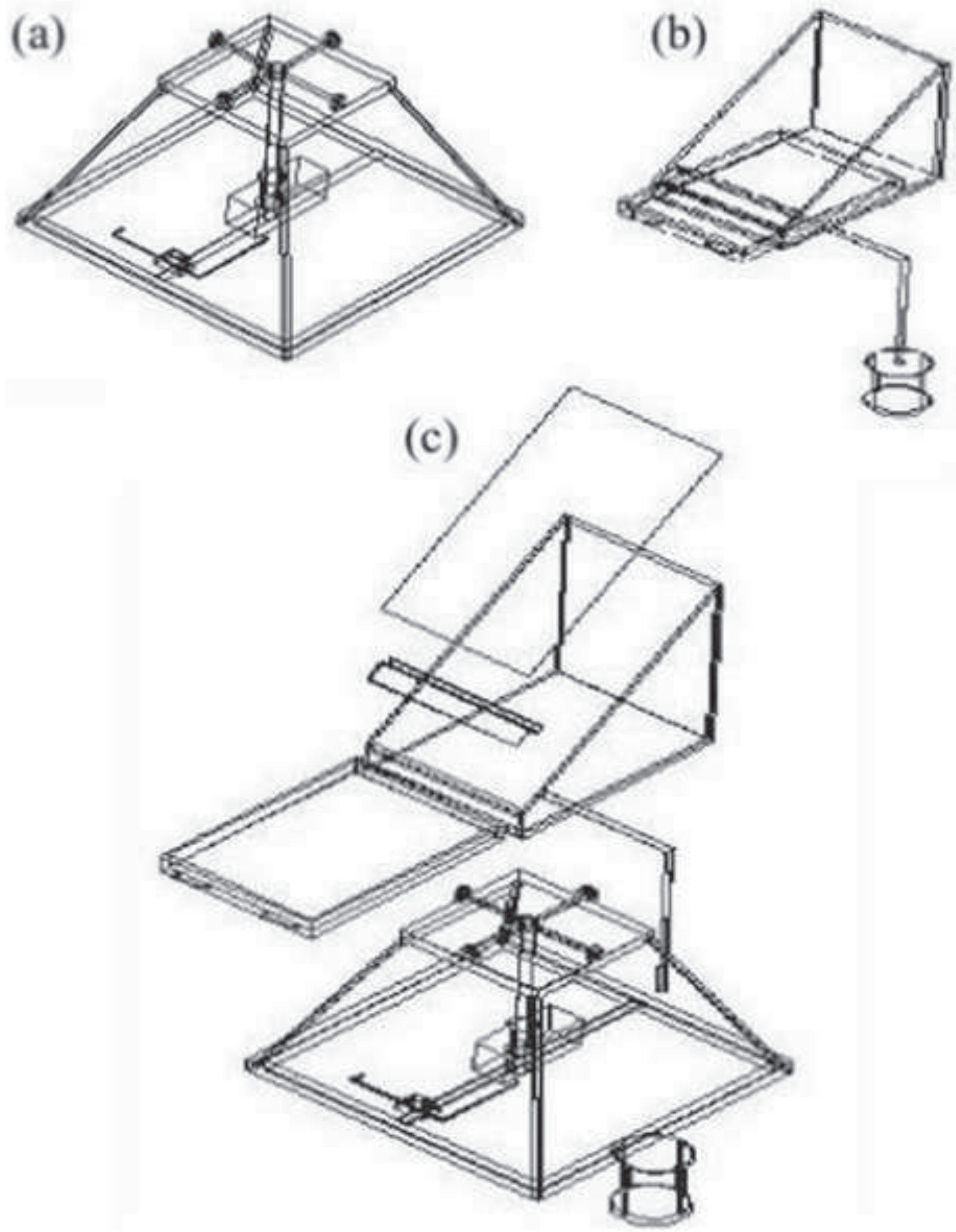

Three-dimensional view of the sun tracking distiller. (a) base, motor and bearing. (b) Distiller. (c) All involved parts of the distiller and tracking system. 


\section{Click here to download high resolution image}

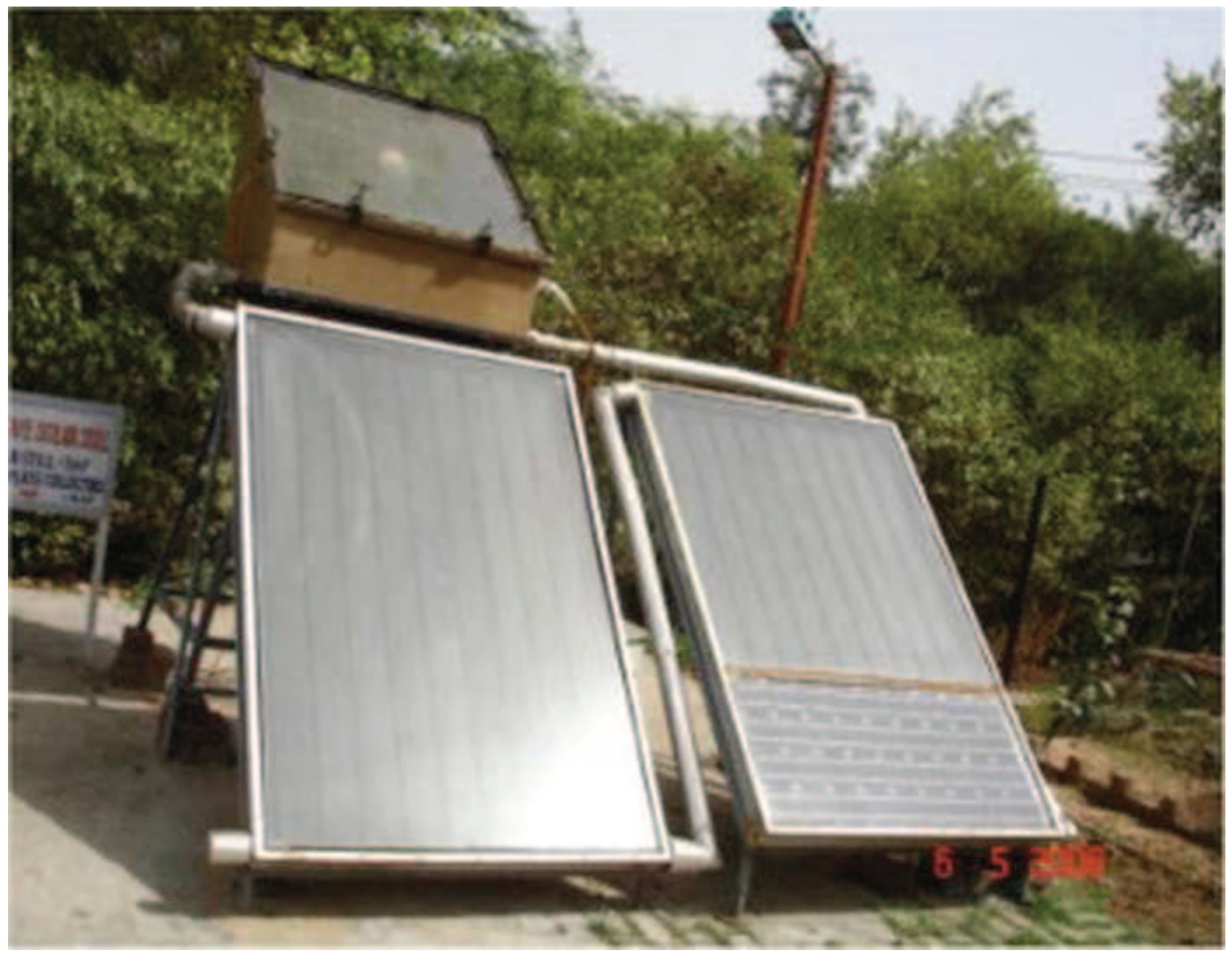




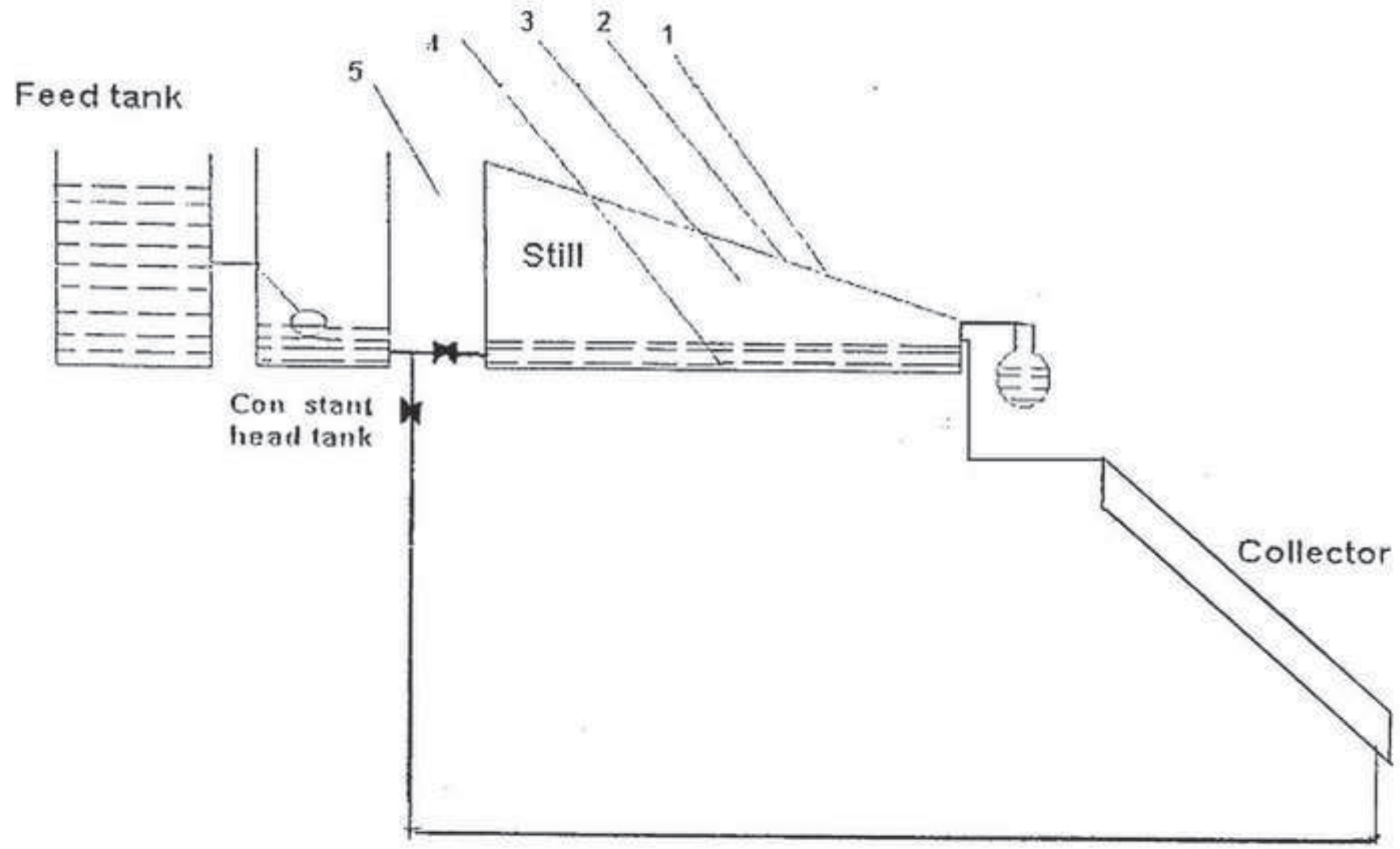




\section{Click here to download high resolution image}

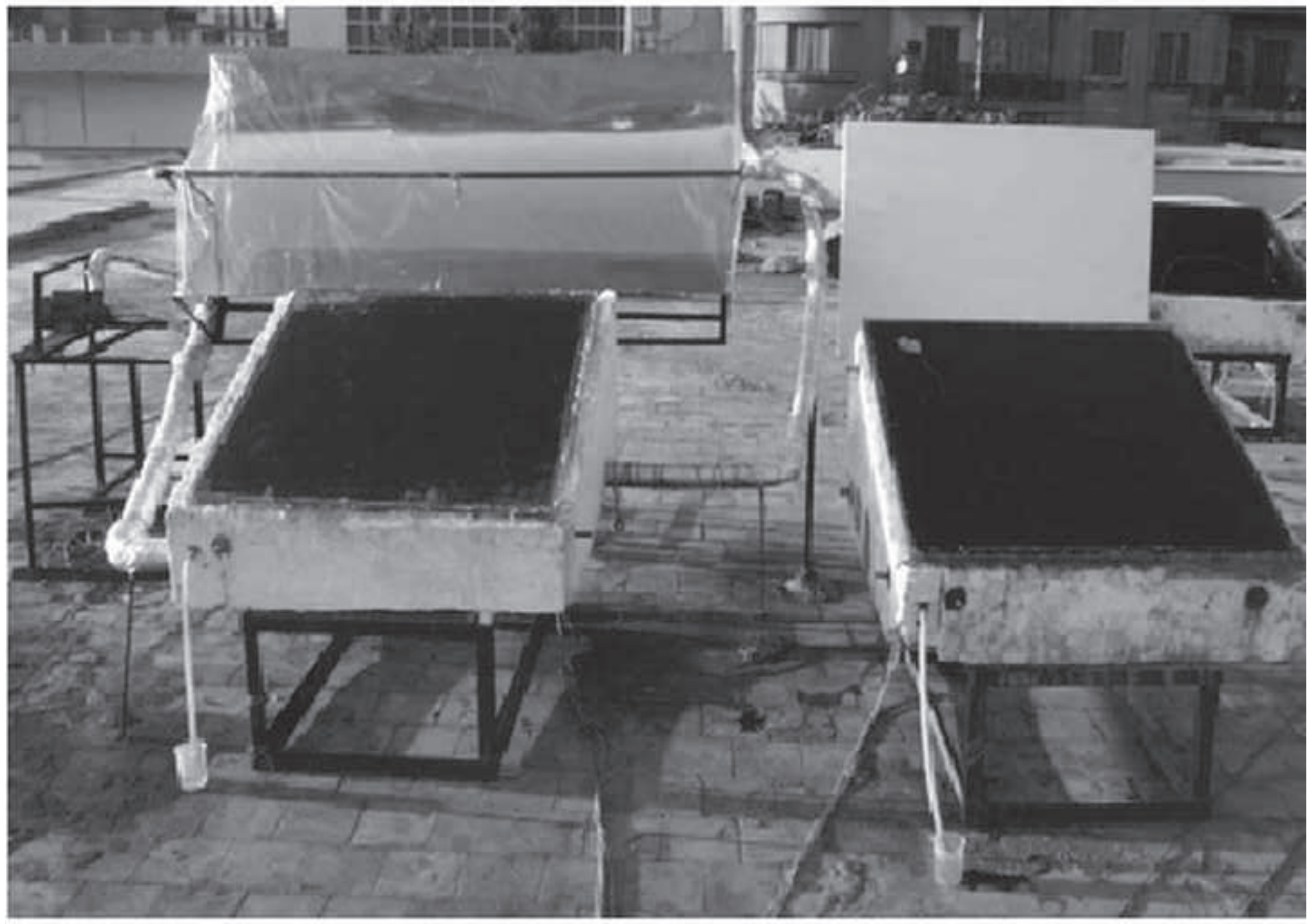




\section{Click here to download high resolution image}

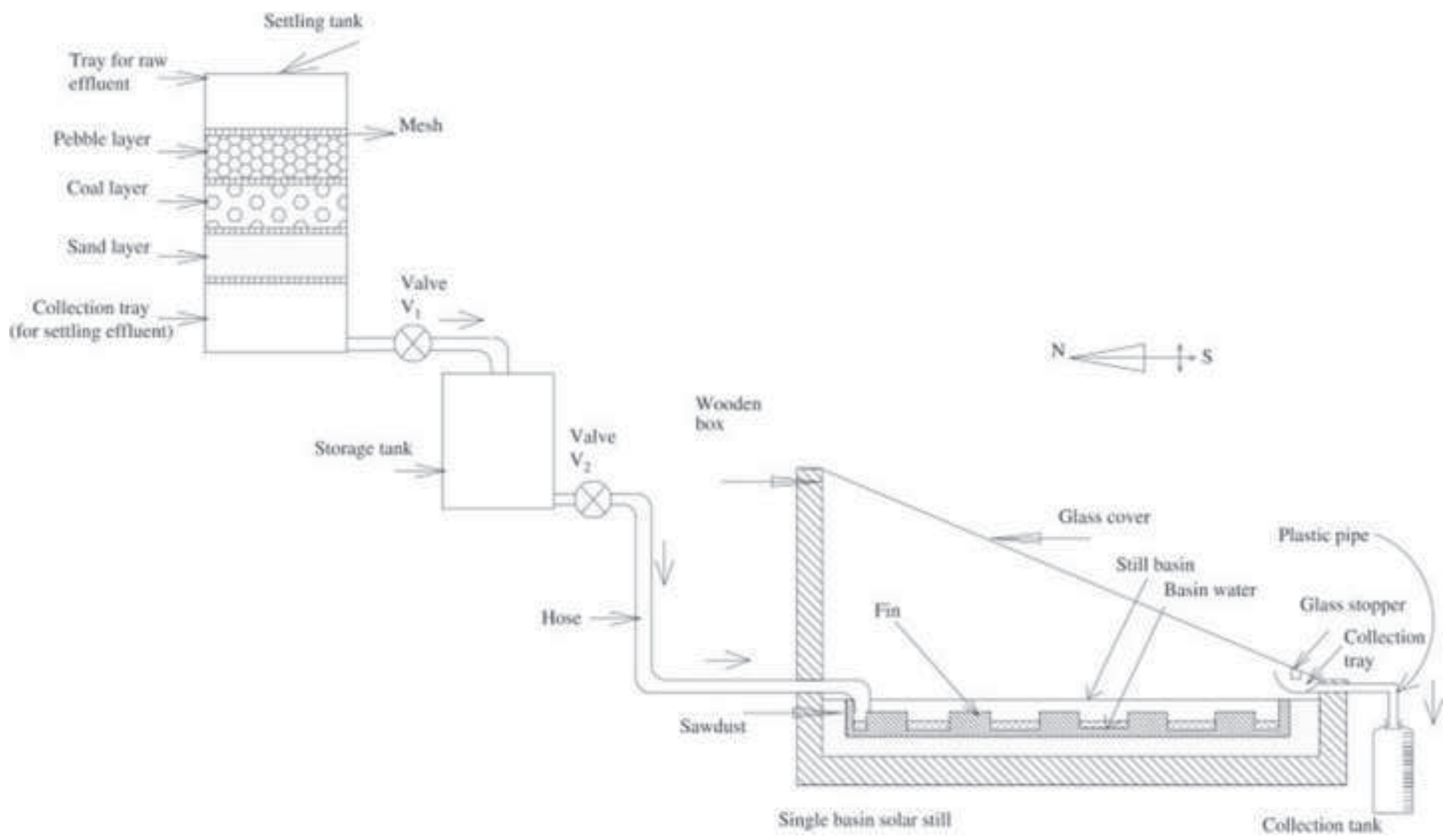



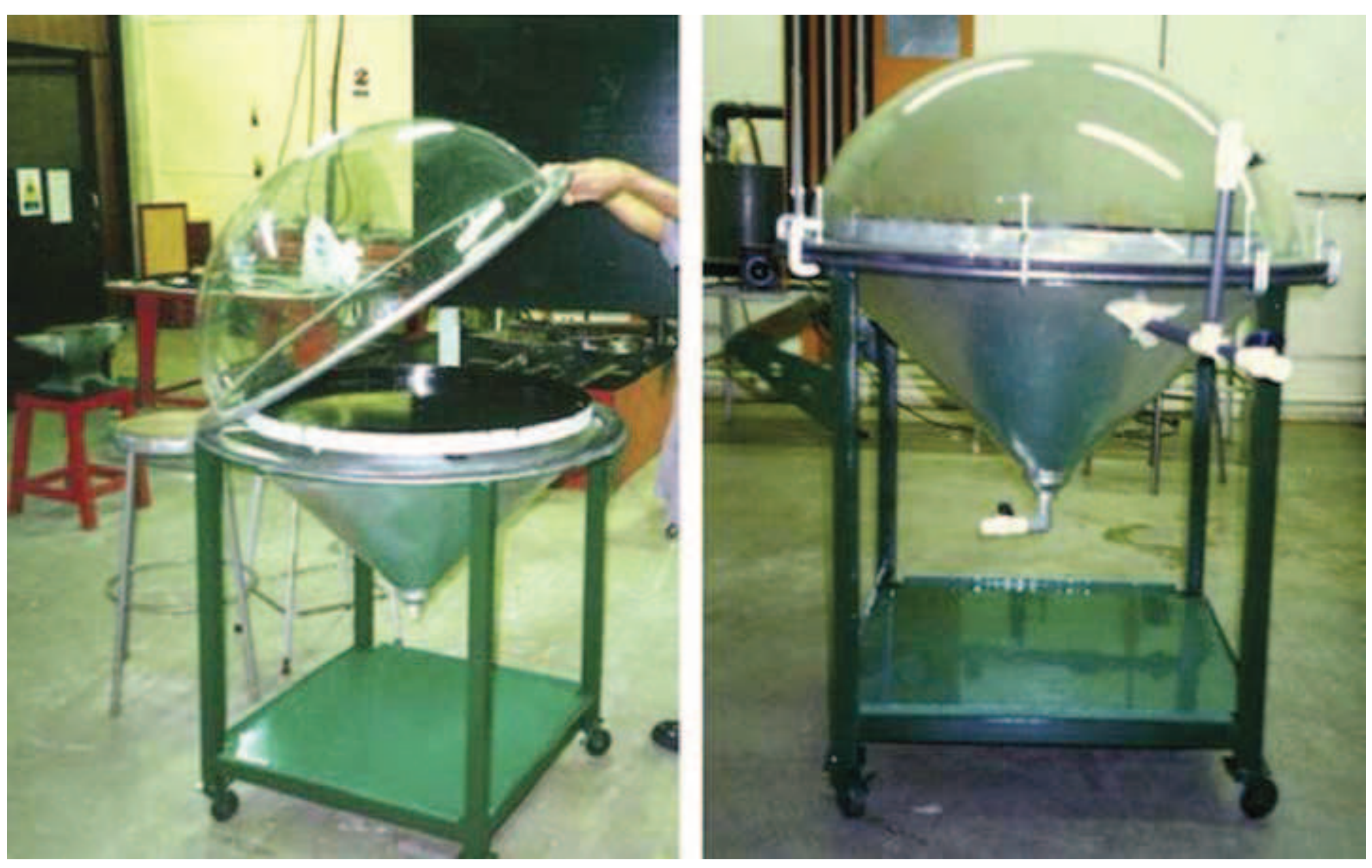


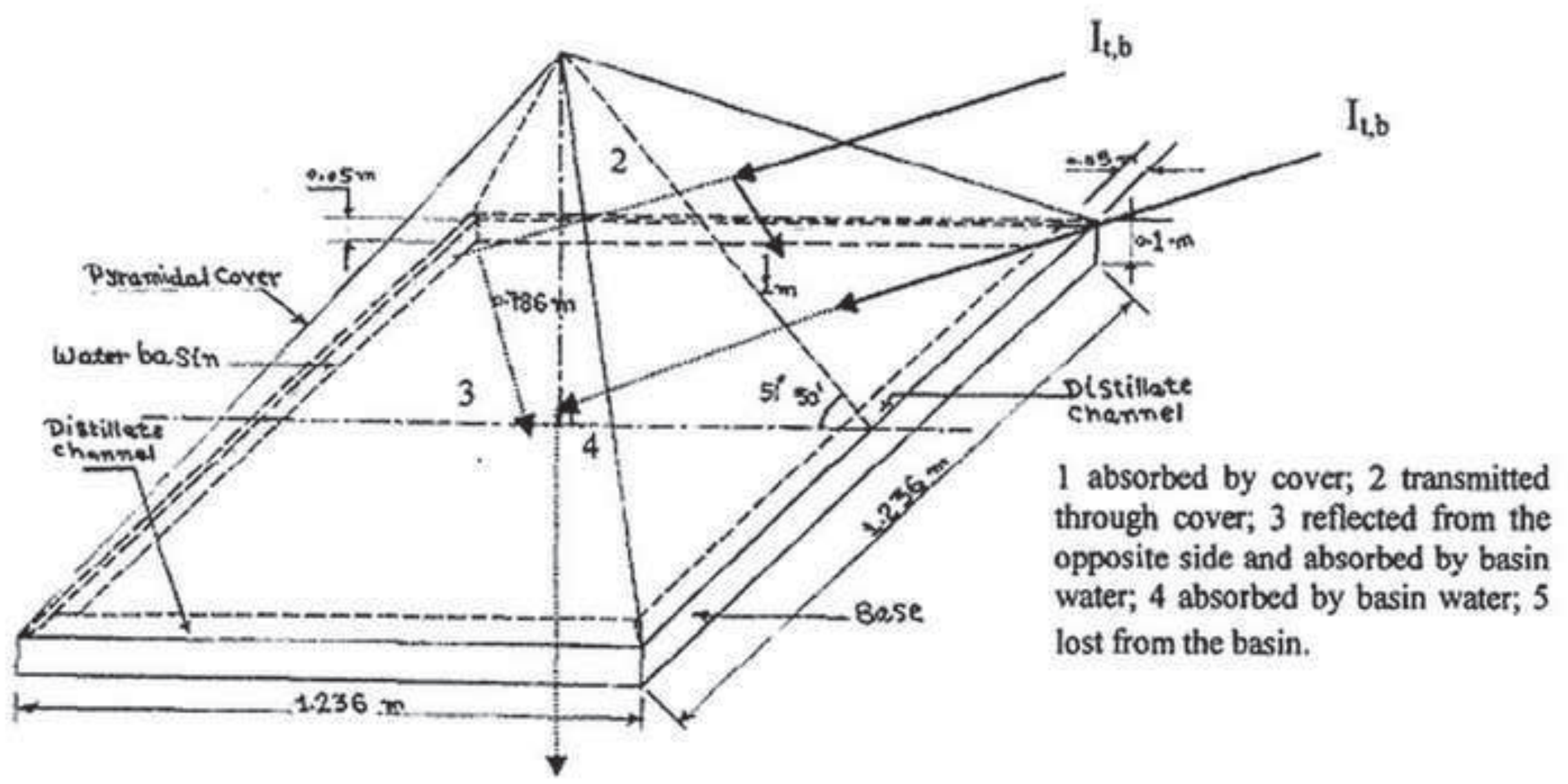




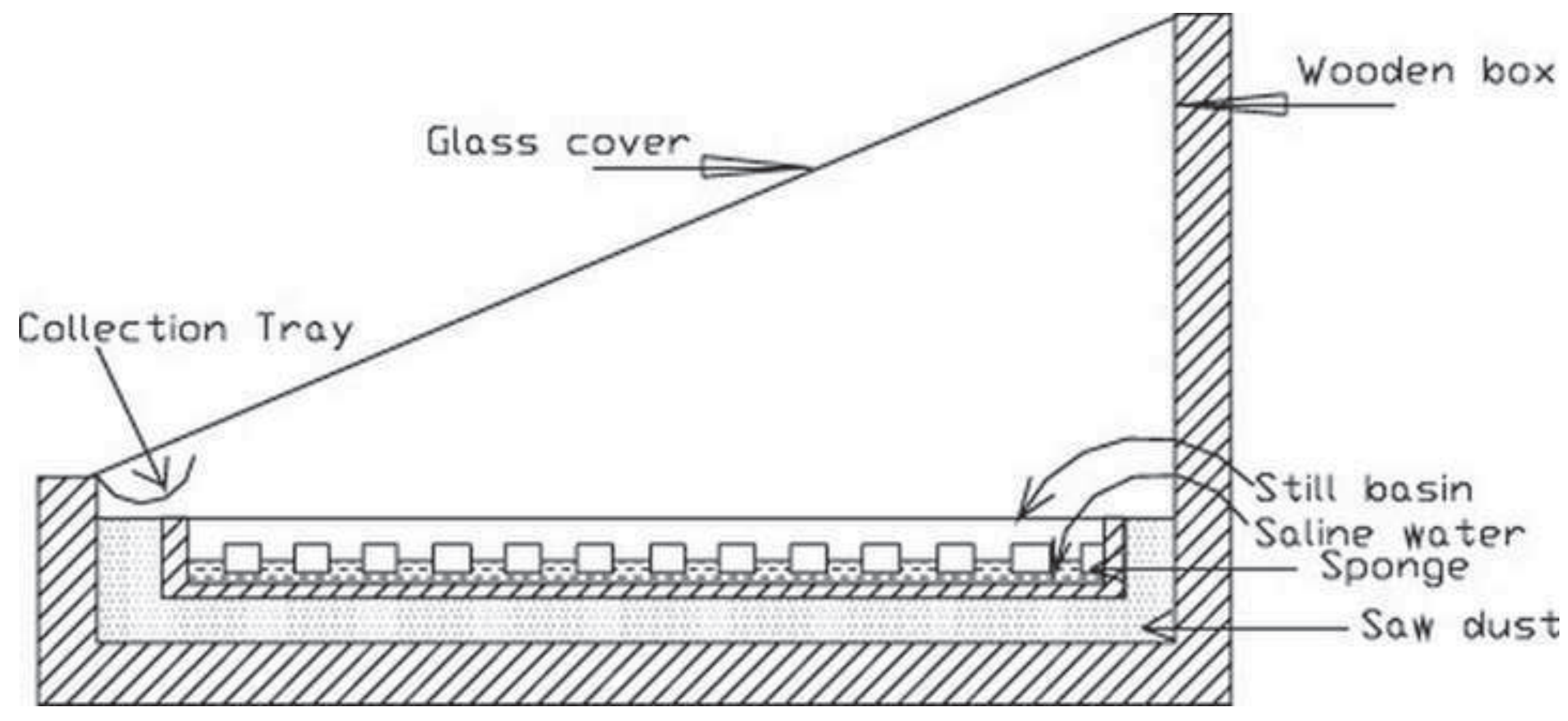




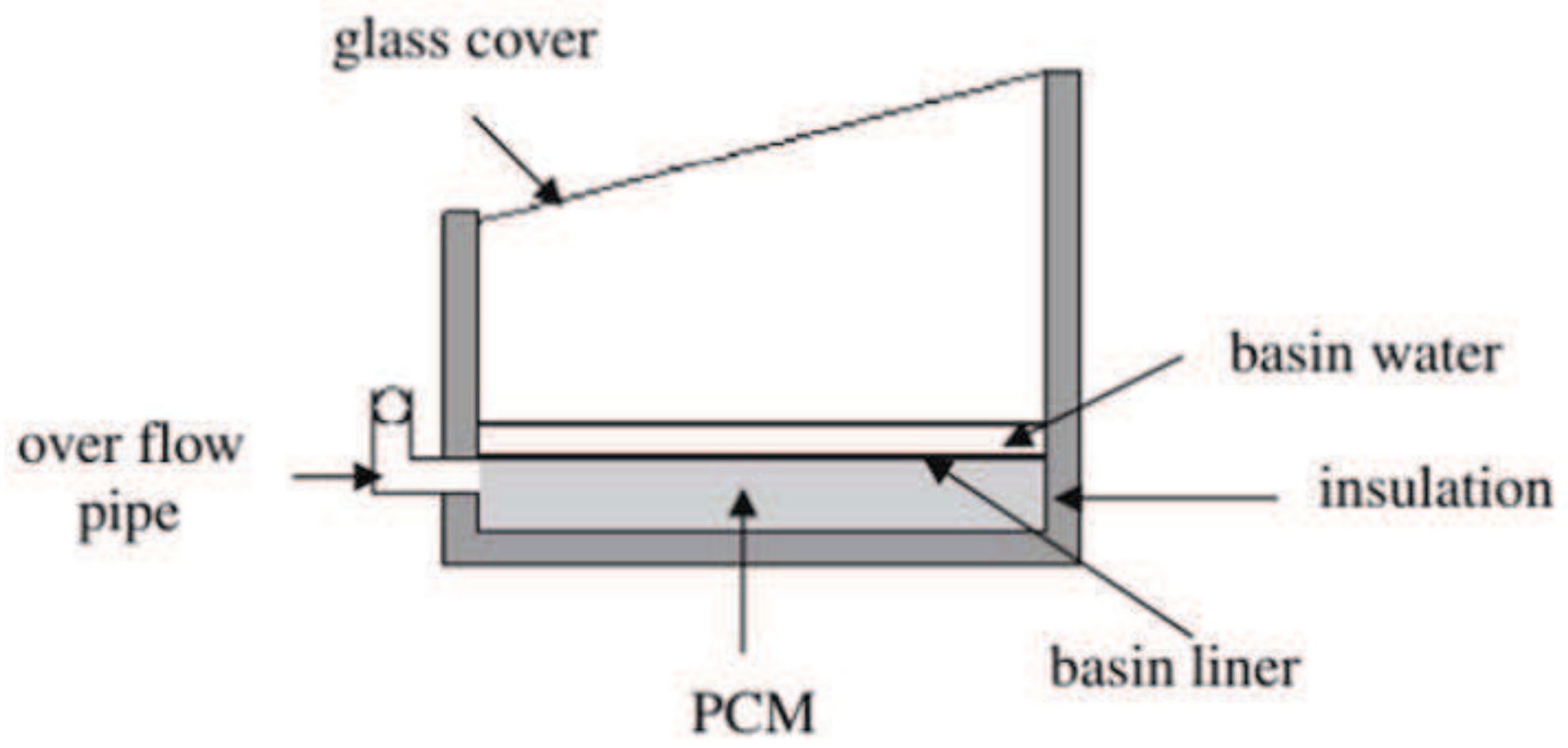




\section{Click here to download high resolution image}

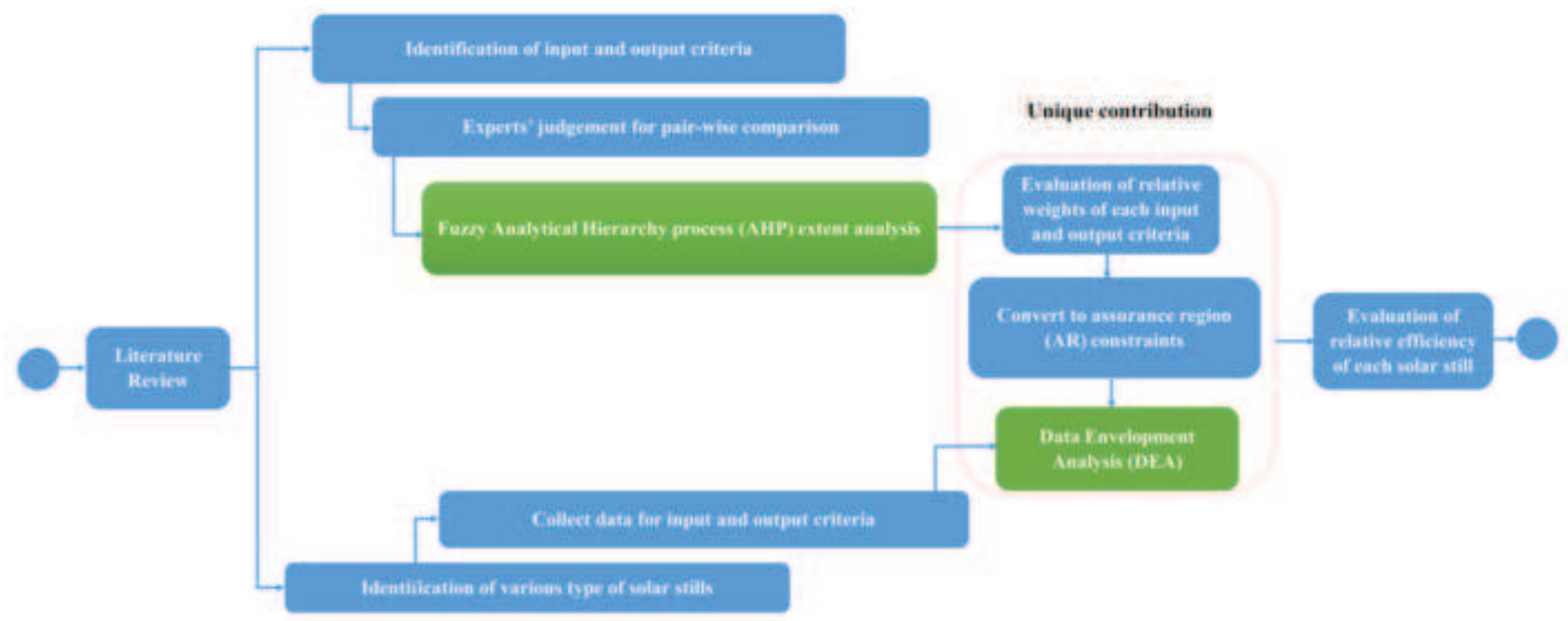




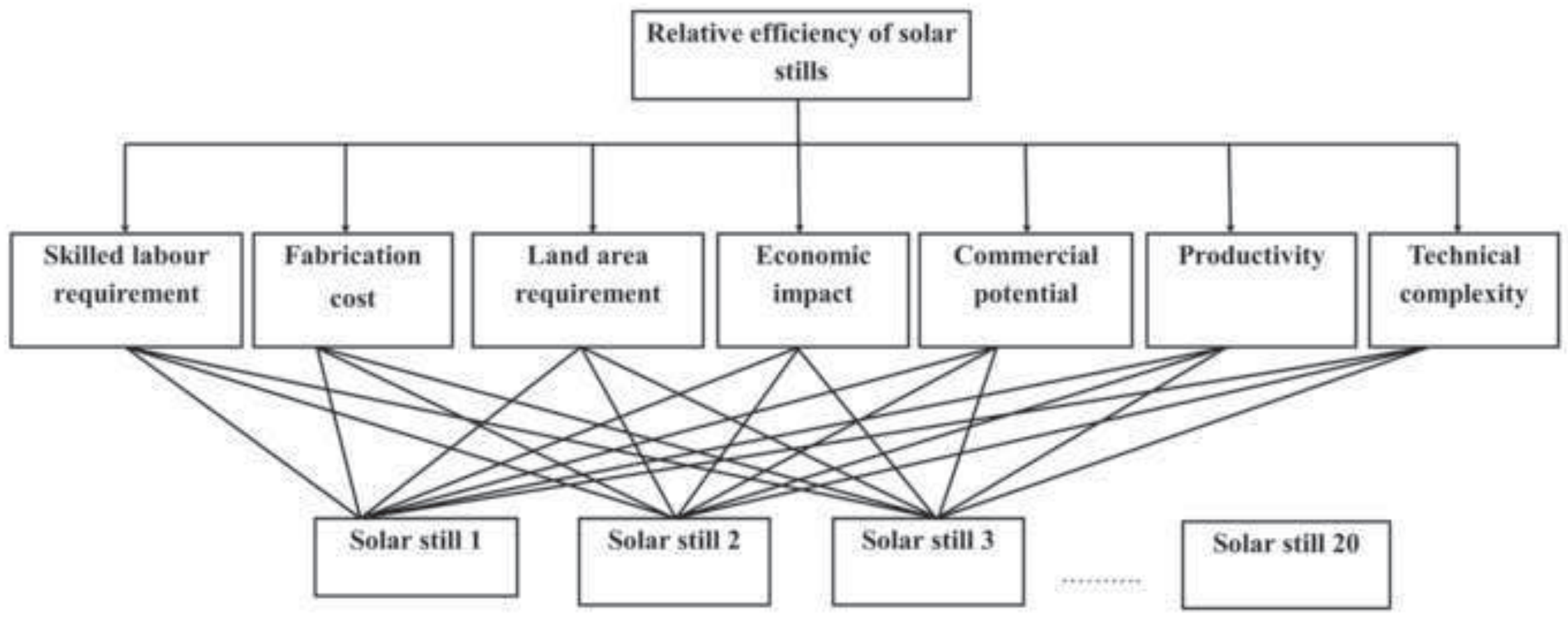




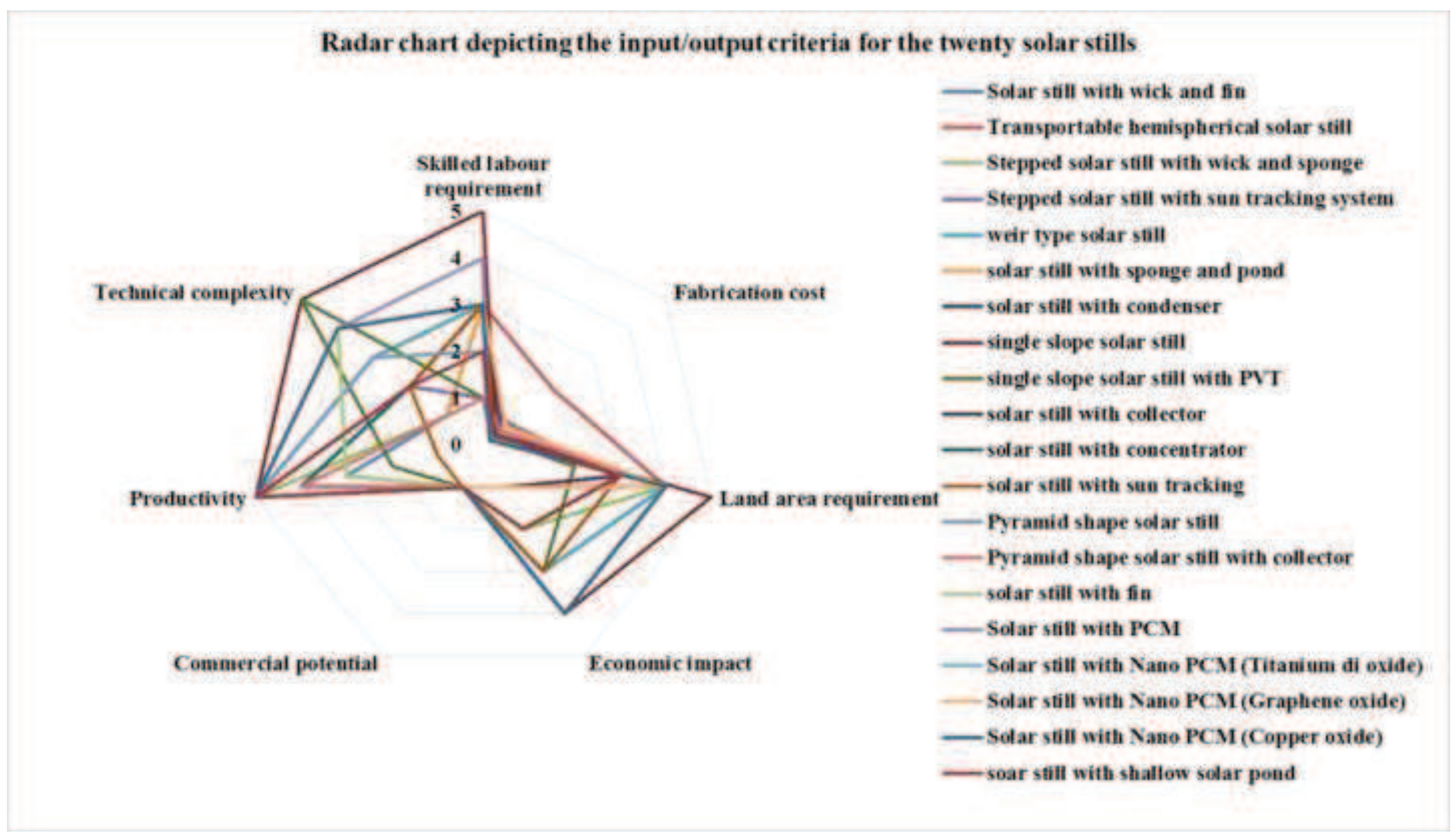




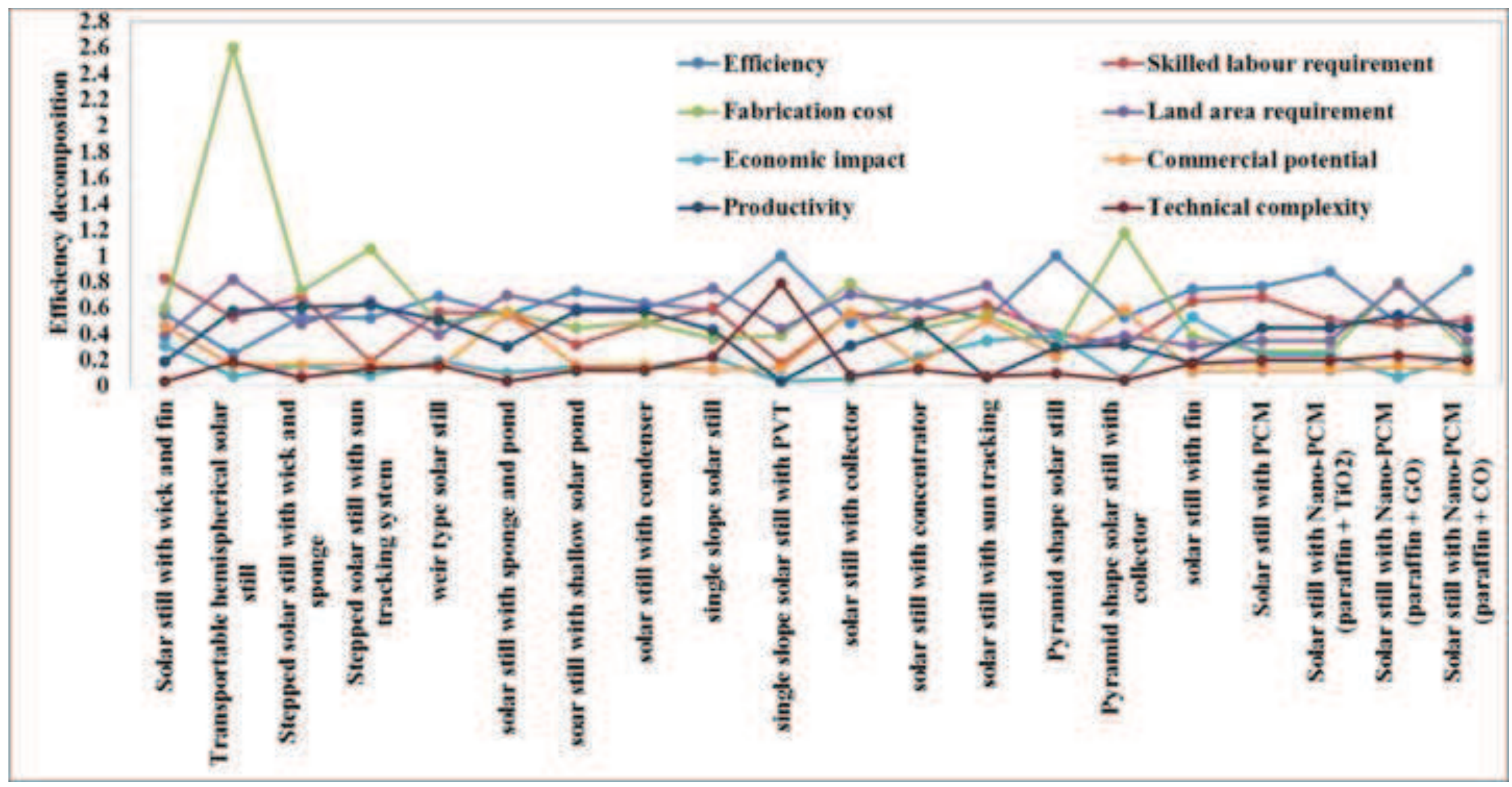

